\title{
ESSAY
}

\section{FEMINISM VERSUS MULTICULTURALISM}

\author{
Leti Volpp*
}

To posit feminism and multiculturalism as oppositional is to assume that minority women are victims of their cultures. This assumption, as Professor Volpp illustrates in this Essay, is achieved by a discursive strategy that constructs gender subordination as integral only to certain cultures. She traces the origins of the ubiquitous claim that minority and Third World cultures are more subordinating than culture in the West to the history of colonialism, the origins of liberalism, depictions of the feminist subject, and the use of binary logic. Pitting feminism against multiculturalism has certain consequences: It obscures the influences that in fact shape cultural practices, hides the forces besides culture that affect women's lives, elides the way women exercise agency within patriarchy, and masks the level of violence within the United States. Professor Volpp concludes by suggesting a basis for a constructive dialogue beyond the discourse of feminism versus multiculturalism.

\section{INTRODUCTION}

The political theorist Susan Moller Okin recently posed the provocative question: Is multiculturalism bad for women? ${ }^{1}$ According to Okin,

* Assistant Professor, American University, Washington College of Law. This Essay was originally delivered as the 1999 James A. Thomas Lecture at Yale Law School, and was subsequently given at the American Bar Foundation, the U.C. Davis Law School Faculty Workshop Series, the MIT Women's Studies Department, the Cornell Law School Feminism and Legal Theory Workshop, the Washington College of Law Junior Faculty Workshop, as a Feminist Legal Theory Lecture at Villanova Law School, and to Peter M. Cicchino's Jurisprudence class at the Washington College of Law. I received extremely helpful feedback at each of these sites. My deep gratitude to Muneer Ahmad, Michelle Anderson, Richard Banks, Devon Carbado, Peter Cicchino, Adrienne Davis, David Eng, Martha Fineman, Mitu Gulati, Bonnie Honig, Kevin Johnson, Kunal Parker, Joel Paul, Catherine Powell, Jamin Raskin, Sherene Razack, Teemu Ruskola, Ann Shalleck, Sophie Volpp, and Joan Williams for their very thoughtful suggestions. Anita Mitra, Catherine Ng, Rahul Shah, and Leah Werchick provided valuable research assistance. I would additionally like to thank Kari Hong, Aziz Huq, and the Columbia Law Review editors for their excellent editorial assistance.

1. Susan Moller Okin, Is Multiculturalism Bad for Women?, in Is Multiculturalism Bad for Women? 7, 9 (Joshua Cohen et al. eds., 1999) [hereinafter Is Multiculturalism Bad for Women?]. Okin's essay first appeared in the Boston Review, and was suhsequently republished in a volume with responses by Katha Pollitt, Will Kymlicka, Bonnie Honig, Azizah Y. al-Hibri, Yael Tamir, Sander L. Gilman, Abdullahi An-Na'im, Robert Post, Bhikhu Parekh, Saskia Sassen, Homi K. Bhabha, Cass R. Sunstein, Joseph Raz, Janet E. Halley, and Martha C. Nussbaum. Is Multiculturalism Bad for Women?, supra, at v-vi. Of these respondents, Honig, Gilman, and Bhabha question Okin's fundamental premise that Western liberal societies are definitionally less gender-subordinating than minority immigrant communities, as I do in this paper. Homi K. Bhabha, Liberalism's Sacred Cow, 
until the past few decades minorities were expected to assimilate; now such assimilation is "considered oppressive." ${ }^{2}$ This, she suggests, raises a dilemma: What should be done when claims of minority cultures or religions contradict the norm of gender equality that is at least formally endorsed by liberal states?

As examples of the clash of cultures that can ensue, Okin proffers Muslim schoolchildren wearing head scarves, polygamous marriages in African immigrant communities, and female clitoridectomy in African immigrant communities in France and the United States. ${ }^{3}$ 1n addition, Okin describes four other types of cases that have surfaced in the United States. These are the marriages of children or marriages that are otherwise coerced (which she illustrates with an example involving lraqi immigrants), Hmong marriage by capture, parent-child suicide by Japanese and Chinese immigrants, and "wife-murder by immigrants from Asian and Middle Eastern countries whose wives have either committed adultery or treated their husbands in a servile way." 4

Faced with this list, Okin concludes that we have too quickly assumed that feminism and multiculturalism ${ }^{5}$ are both good things that are easily reconciled. ${ }^{6}$ While she does acknowledge that "Western cultures, of course, still practice many forms of sex discrimination," 7 and notes that "virtually all of the world's cultures have distinctly patriarchal pasts," 8 she asserts that some cultures-mostly, she says, Western liberal cultures"have departed far further from [these pasts] than others." Her conclusion: Female members of "a more patriarchal minority culture" may "be much better off if the culture into which they were born were either to become extinct (so that its members would become integrated into the

in Is Multiculturalism Bad for Women?, supra, at 79, 79-80; Sander L. Gilman, "Barbaric" Rituals?, in Is Multiculturalism Bad for Women?, supra, at 53, 57-58, Bonnie Honig, "My Culture Made Me Do It," in Is Multiculturalism Bad for Women?, supra, at 35, 36-37, 40; Okin, supra, at 22-23. An-Na'im similarly raises the issue of Okin's failure to address economic rights, although he separates the question of economic rights from the issue of gender. Abdullahi An-Na'im, Promises We Should All Keep in Common Cause, in Is Multiculturalism Bad for Women?, supra, at 59, 61-62.

2. Okin, supra note $1,7-10$.

3. Id. at $9-10,18$.

4. 1d. at 18 .

5. Okin identifies feminism as "the belief that women should not be disadvantaged by their sex, that they should be recognized as having human dignity equal to that of men, and that they should have the opportunity to live as fulfilling and as freely chosen lives as men can." Id. at 10. She defines multiculturalism as the claim "that minority cultures or ways of life are not sufficiently protected by the practice of ensuring the individual rights of their members, and as a consequence these should also be protected through special group rights or privileges." ld. at 10-11.

6. Id. at 22-23.

7. 1d. at 16 .

8. Id.

9. Id. 
less sexist surrounding culture),"10 or if the culture were "encouraged to alter itself so as to reinforce the equality of women. . .." 11

But is Okin correct to posit multiculturalism and feminism as contradictory? I argue here that posing multiculturalism and feminism as oppositional results in a discourse of "feminism versus multiculturalism" that is premised on serious and fundamental logical flaws. Such a discourse relies upon a particular subject, the immigrant woman victim of minority culture. In examining how the figure of the immigrant woman victim is constructed, I address both the theoretical bases of the feminism versus multiculturalism discourse and the disturbing consequences of its adoption. ${ }^{12}$

An example might help to illustrate the troubling nature of this discourse. I was asked to present a talk at a certain university. As I described its contents and suggested the title, "Feminism versus Multiculturalism," an organizer of the event suggested changing the name of the talk to "Is it OK to Beat My Wife?" She asserted that the graphic title would draw more people than my far more abstract and confusing title of "Feminism versus Multiculturalism." But why would this be so? The proposed title reinscribed certain popular assumptions-that there exist communities

10. Id. at 22-23.

11. Id. at 23. 1 am not addressing here the claims Okin makes about religion. See id. at 14, 16. For a response to Okin's discussion of religion, see Martha C. Nussbaum, A Plea for Difficulty, in Is Multiculturalism Bad for Women?, supra note 1, at 105 (describing Okin's depiction of religion as "little more than a bag of superstitions frequently organized around the aim of inaintaining control over women," and expressing concern that this depiction evinces contempt and precludes the respect necessary to understand religious difference).

12. It should be clear that the focus here is a critical examination of the feminism side of the feminism versus multiculturalism discourse. An examination of what "multiculturalism" represents in this discourse would require another article that I cannot tackle here. Multiculturalism has variously and contradictorily been described as anti-racist or as oblivious to racism, as representing cultural autonomy or as revisiting a common culture, as grounded in grassroots alliances or corporate diversity management, and as linking or separating politics and culture. See Avery F. Gordon \& Christopher Newfield, Introduction to Mapping Multiculturalism 1, 3-7 (Avery F. Gordon \& Christopher Newfield eds., 1996). Multiculturalism has also been separated into "strong inulticulturalism" and "weak multiculturalism," which carry different assumptions and commitments. See Stanley Fish, Boutique Multiculturalism, in Multiculturalism and American Democracy 69, 69-70 (Arthur M. Melzer et al. eds., 1998). For a survey of the differing meanings of multiculturalism, see Multiculturalism: A Critical Reader 1-3, 7-12 (David Theo Goldberg ed., 1994) (describing multiculturalism as standing in for a wide range of social articulations, ideas, and practices); David Bennett, Introduction to Multicultural States: Rethinking Difference and ldentity 1-2 (David Bennett ed., 1998) (describing multiculturalism as a contested term representing differing agendas); Amy Gutmann, Introduction to Multiculturalism: Examining the Politics of Recognition 4 (Amy Gutmann ed., 1994) (describing multiculturalism as the recognition of "distinct cultural identities of members of a pluralistic society"); Ayelet Shachar, The Puzzle of Interlocking Power Hierarchies: Sharing the Pieces of Jurisdictional Authority, 35 Harv. C.R.-C.L. L. Rev. 385, 390-92 (2000) (describing strong and weak versions of multiculturalism). 
of people who think it may be perfectly appropriate to engage in domestic violence, namely, those who are too ignorant, too primitive, too backward to know any better. The title also pointed to the parameters of the debate that normally frames the discussion of feminism and multiculturalism: Group one argues it is OK for me to beat my wife, and the other group argues no, we have universal feminist principles that would never allow you to beat your wife.

The argument between these two positions has limited utility. What is much more interesting to explore is the question of why this binary discourse so frequently structures the parameters of the debate. My criticism of the structure of the discourse of feminism versus multiculturalism does not stem from the perspective of cultural relativism. Rather, it starts from the position that we can make normative choices, such as, it is never "OK to beat one's wife." The clarification is essential because any criticism of the way these values are formulated is frequently considered a purely deconstructive project or viewed as a very quick slide down the slippery slope of relativism. ${ }^{13}$ The thrust of my argument is not that we ought to eliminate or dismiss feminist values, but to suggest they will broaden and shift when we examine immigrant and Third World women in a more accurate light.

This Essay constitutes part of a larger project that examines the relationship between gender, race, culture, and the law. ${ }^{14}$ My purpose here

13. For an example of how this kind of criticism can be met with a charge of relativism, see Leslye Obiora et al., Situating a Critic in Her Discourse: A Conversation, 4 Circles Buff. Women's J.L. \& Soc. Pol'y 73 (1996) [hereinafter Situating a Critic]. What is stunning about the interchange contained in these pages is the way the binary nature of the classic debate inhibits dialogue. The written text begins in the middle of a conversation. Monica Jardine has, at a workshop where Leslye Obiora was speaking about female genital surgeries, "expressed sincere exasperation over what she discerned as a reductionist approach that ultimately conceptualizes the issue in terms of racial politics." Id. at 73. Obiora agrees that female circumcision should not be understood as a "BlackWhite" or "North-South" issue, and explains that her remarks address how damaging polarization of the dialogue on female genital surgeries is to the movement to end that practice. Id. at 73-74. She notes that moderate voices have been silenced amidst the sensationalism which polarizes female circumcision as either the relic of a barbaric past or the safe haven of culture and tradition. She writes that the problem is complex and deeply embedded, and that the campaign against female circumcision is characterized by certain disturbing aspects, including its threat to grassroots mobilization. Obiora's comments fill several pages. See id. at 73-80. Jardine responds in eight sentences. See id. at 80 . She refers to Obiora as "Comrade Obiora" and states that Obiora does not identify with African feminists who want to see the practice end immediately because "she wants to make accommodations with 'traditional' African cultural practices." Id. Reacting, Obiora writes that she is "taken aback by the brevity and tone of [Jardine's] remarks," which is especially unfortunate because her enthusiasm for the forum was prompted by the opportunity to communicate about the debates surrounding female circunicision. Id.

14. This Essay should also be understood as situated within a broader discourse of writers who have made similar interventions in other disciplines, such as Inderpal Grewal, Chandra Mohanty, Uina Narayan, and Sherene Razack. For an excellent description of this broader discourse, see Mâivan Clech Lâm, Multicultural Feminism, in International Encyclopedia of the Social and Behavioral Sciences (forthcoming 200I) (on file with the 
is to identify foundations for a new discourse that would move beyond binary oppositions in examining the concerns of women cross-culturally or globally. ${ }^{15}$ It is necessary to push the dialogue past the liberal feminist claim of writers like Okin-as well as past the traditional response of solely calling such claims imperialist-by investigating that which underlies what we understand as our values. Part I of this Essay illustrates how feminist discourse on particular forms of patriarchy reinscribes the idea that non-Western women are quite literally vulnerable to death by culture. This is due to the assumption that non-Western women are situated within cultural contexts that require their subordination, achieved by a discursive strategy that constructs gender subordination as integral to their culture. In Part II, I discuss the theoretical underpinnings of the ubiquitous claim that minority and Third World cultures are more subordinating than Western culture, tracing its roots in the history of colonialism, liberalism, depictions of the feminist subject, and binary logic. Part III addresses the consequences of the feminism versus multiculturalism discourse, namely how it obscures the forces that actually shape culture, hides what forces beyond culture impact women's lives, denies that women have agency within patriarchy, and elides the level of violence intrinsic to the United States. I conclude by suggesting the basis for a constructive dialogue beyond the discourse of feminism versus multiculturalism.

\section{Death by Culture}

The discourse of feminism versus multiculturalism presumes that minority cultures are more patriarchal than Western liberal cultures. ${ }^{16} \mathrm{Be}$ -

Columbia Law Review) (describing the "growing literature and practice of feminism that ... advocates for the [] empowerment [of women] within the specific contexts of their cultures and societies").

15. Martha Minow astutely outlines these binary oppositions in her recent essay, About Women, About Culture: About Them, About Us, Daedalus, Fall 2000, at 125, 129-38.

16. The "minority" cultures depicted in the feminism versus multiculturalism discourse are immigrant, and not African-American, cultures. Arguably, minority immigrant cultures occupy diametrically opposed spaces in the U.S. imagination: either as positive, in the form of culture one wants to consume (for example, ethnic food, Oriental rugs, henna tattoos) or as negative, in the form of culture one wants to expel (for example, gender-subordinating practices). African-American culture (especially black urban culture) seems to occupy primarily a space of pathology in the U.S. imagination, although not along the same presumed gender subordinating lines as minority immigrant cultures. In fact, one form of pathology African-American culture has been alleged to take is that African-American masculinity has been threatened by black women. One could look to the Moynihan Report and its premise that the "dominance" of black women led to "humiliated" black men, welfare dependency, and a "tangle of pathology." Paula Giddings, When and Where I Enter: The Impact of Black Women on Race and Sex in America 325-35 (1984) (quoting and discussing the Moynihan Report) (citation omitted). On the construction of black urban culture as pathological, see generally Robin D.G. Kelley, Yo' Mama's Disfunktional!: Fighting the Culture Wars in Urban America 15-42 (1997) (arguing that social scientists have contributed to a construction of the ghetto as a reservoir of pathologies and bad cultural values). 
cause representations of minority women are often interchanged with those of Third World women, the depiction of minority cultures in this discourse often reflects assumptions about Third World cultures. ${ }^{17}$ Thus, both immigrants of color and Third World communities are necessarily the subject here. ${ }^{18}$

Since the vision of the suffering immigrant or Third World woman and the liberated Western one has so strong a hold on the American imagination, I attempt to demonstrate that the presumption of Western women's liberation depends upon the notion that immigrant and Third World communities are sites of aberrant violence. ${ }^{19}$ In this Section, I elucidate this fact by contrasting narratives of here versus there, of us versus them. Part of the reason many believe the cultures of the Third World or immigrant communities are so much more sexist than Western ones is that incidents of sexual violence in the West are frequently thought to

17. The fungibility of these representations reflects the assumption that immigrants import wholesale their culture from their countries of origin. The representation of Third World women in the feminism versus multiculturalism discourse concurs with their representation in the universalism versus cultural relativism debate, which is also the subject of this Essay. As a question of terminology, none of the terms used to describe regions of the world variously labeled Third World, developing, less developed, underdeveloped, the global South, the East, non-Western, and, now, emerging markets is entirely satisfactory. 1 recognize the limits of the term "Third World," but use it, primarily because of greater problems associated with these other terms. For a discussion of the inadequacies and benefits of the term "Third World," see Karin Mickelson, Rhetoric and Rage: Third World Voices in International Legal Discourse, 16 Wis. Int'l L.J. 353, 355-62 (1998).

There is enormous heterogeneity masked by the use of any of these terms. One point of interest is why certain regions, nations, and religions most often stand in for the idea of the "Third World" in particular contexts. In terms of the suffering "Third World" woman, it is worth asking why they are localized in certain areas. Why the prevalence of Islam? of South Asia? African women seem to be the object of concern primarily when the subject is "female genital mutilation." Indian women seem to stand in for "real" suffering in feminist writing in a peculiar way.

18. I recognize that there are risks to replicating the blurring of minority immigrant and Third World communities as I do here by describing the fact of this fungibility. Pinning the origins of gender subordination within immigrant communities to their country of origin abdicates the United States's responsibility for the behavior of immigrants (through gender subordination, for example, in the form of immigration law) and also elides immigrants' assimilation into an American culture of gender subordination.

I recognize, as well, that in criticizing the feminism versus multiculturalism discourse, I am inevitably reducing other complexities, for example, by discussing "immigrant women" as if they constitute a singular group. Unfortunately, this kind of reduction seems inevitable when criticizing what is an even more reductionist representation.

19. This notion is structured through geopolitical dynamics. As Inderpal Grewal points out, "[d] iscourses of North America as a site of freedom and human rights creates 'American' subjects who uphold this belief and assert it through their relations, [both] feminist and non-feminist, with others around the world." Inderpal Grewal, "Women's Rights as Human Rights": Feminist Practices, Global Feminism, and Human Rights Regimes in Transnationality, 3 Citizenship Stud. 337, 340 (1999) [hereinafter Grewal, Women's Rights]. 
reflect the behavior of a few deviants-rather than as part of our culture. In contrast, incidents of violence in the Third World or immigrant communities are thought to characterize the cultures of entire nations. ${ }^{20}$

Culture is invoked to explain forms of violence against Third World or immigrant women while culture is not similarly invoked to explain forms of violence that affect mainstream Western women. The specific case of dowry and domestic violence murders provides an example of this phenomenon. Dowry murders take place when a new wife is murdered, usually burned to death, in connection to escalating dowry demands. Dowry murders are thought of as a peculiar indicator of the extreme misogyny of India and are frequently confused with sati-the widow immolation supposedly justified by Hindu scripture that rarely takes place in contemporary India. Recently an article in The New Yorker about arranged marriages in South Asian communities contained the suggestion that dowry murders are the cultural alternative to Western divorce-a way to exit relationships. ${ }^{21}$ Instead, as some have pointed out, the more appropriate analogy is to equate dowry murders with domestic violence, and specifically, domestic violence murders in the United States. ${ }^{22}$ The philosopher Uma Narayan has calculated that death by domestic violence in the United States is numerically as significant a social problem as dowry murders in India. ${ }^{23}$ But only one is used as a signifier of cultural backwardness: "They burn their women there." As opposed to: "We shoot our women here." Yet domestic violence murders in the U.S. are just as much a part of American culture as dowry death is a part of lndian culture. In the words of Narayan, when "cultural explanations" are given for fatal forms of violence only in the Third World, the effect is to suggest that Third World women suffer "death by culture."24

20. I give other examples of this phenomenon which involve adolescent marriage in Leti Volpp, Blaming Culture for Bad Behavior, 12 Yale J.L. \& Human. 89, 91-93 (2000) [hereinafter Volpp, Blaming Culture]. Lama Abu-Odeh has similarly examined crimes of honor in the Arab world and the killing of women in the heat of passion in the United States. In each legal system, killing women is either fully or partially tolerated by law, "reveal [ing] the fallacy of . . . the orientalist construction that the East is different from the West." Lama Abu-Odeh, Comparatively Speaking: The "Honor" of the "East" and the "Passion" of the "West," 1997 Utah L. Rev. 287, 290.

21. Philip Gourevitch, Letter from Queens: A Husband for Dil, The New Yorker, Feb. 22 \& Mar. 1, 1999, at 78, 80.

22. See Uma Narayan, Dislocating Cultures: 1dentities, Traditions, and Third-World Feminism 95 (1997) (making the argument that dowry murders should be understood as a form of domestic violence).

23. Narayan's research was based upon FBI statistics that indicated roughly 1,400 U.S. women annually were victims of domestic violence murder-a number that appears to only reflect those cases yielding convictions. The lndian government statistic of roughly 5,000 annual dowry murders includes all deaths suspected to be dowry murders-including deaths that yielded no conviction. India's population is roughly four times that of the United States. Thus, Narayan argues, these figures "make plausible the claim that 'death by domestic violence' in the U.S. seems to be numerically as significant a social problem as 'dowry-murders' are in India." Id. at 99.

24. Id. at 84 . 
To show the strength of the image of the Indian woman burnt to death, killed by her culture, we can look at media coverage of the death of Aleyamma Mathew. Mathew, a registered nurse, was burnt to death by her husband, Mathew Varughese, in Texas in 1992,25 after six years of verbal and physical abuse. ${ }^{26}$ Mathew's death was constructed by the media as a synecdoche for Indian culture. ${ }^{27}$ The headline of an article in the Dallas Observer read: "Battered by her husband, Parkland Nurse Aleyamma Mathew remained true to her culture. In the end she became its victim." 28 The cover called her a "burning bride"-conflating her murder with dowry deaths even though she had been married for twenty years. ${ }^{29}$ The article reported that "Aleyamma Mathew may have been fated to die by fire," and confused her murder with sati by stating that, while "[s]ati was outlawed in the late 1800 s, and only a handful of cases have been reported in the last two decades. ... the tradition of wife burning continues." ${ }^{30}$ Note that Aleyamma Mathew was Christian, originally from Kerala in South India, and not Hindu. In other words, she was not even in the relevant category of one who might purportedly engage in sati. $^{31}$ The article further suggested that Mathew died because she confronted "Indian tradition": "[B]efore going to sleep this night, Aleyamma would repeat again what no Indian woman, even in America, says without repercussions: she would tell her husband no." The article later stated that "[b]y the measure of Indian tradition, Mathew Varughese's wife made two mistakes: she gave him only daughters and she dared to tell him no. She paid for it with her life." 32

The representations in this newspaper's account demonstrate what literary theorist Rey Chow has called the "King Kong syndrome," in which the Third World, as "the site of the raw material that is 'monstrosity,' is

25. See Varughese v. State, 892 S.W.2d 186, 189, 193 (Tex. App. 1994) (describing murder); Radhika Parameswaran, Coverage of "Bride Burning" in the Dallas Observer. A Cultural Analysis of the "Other," 16 Frontiers 69, 72 (1996) (same). Varughese's defense theory was that his wife had committed suicide, and attempted to show that suicide by selfimmolation was common among Indian women. This led to the prosecution calling an expert witness who testified that suicide by burning was not very common in India because it was a very painful way to die. The expert witness also noted that there were easier, less painful ways to commit suicide-such as ingesting pesticide, jumping in a well and drowning, or hanging. Transcript of State v. Varughese at 621-22 (No. F-92-1222). The defense counsel responded on cross-examination by asking the expert about sati. See id.

26. Parameswaran, supra note 25 , at $72-73$.

27. ld. at 75 .

28. ld.

29. Id. at 76 (noting the cover's use of the term, and discussing how it has been used by the media and researchers to discuss "dowry deaths").

30. Id. at 80 (emphasis omitted). In fact, sati was banned in 1829. Lata Mani, Contentious Traditions: The Debate on Sati in Colonial India 24 (1998) (describing how sati was outlawed and made punishable by criminal courts).

31. Sati was alleged to be a Hindu, not Christian, practice. 1d. at 18 (describing East India Company circular declaring sati to be a practice founded in the religious beliefs of Hindus).

32. Parameswaran, supra note 25 , at 85 (emphasis omitted). 
produced for the surplus value of spectacle, entertainment, and spiritual enrichment for the "First World." 33 The article focuses on what is considered the "lurid exoticism" of women being burnt. ${ }^{34}$ In fact, the use of fire as the preferred instrument of dowry murder is connected to the Indian context-but not because of exotic culture. ${ }^{35}$ Fire has forensic advantages because it is a simple method of murder, it destroys evidence of murder, and it can look like an accident. As Narayan writes, burning a woman to death in India is no more exotic than shooting a woman to death in the United States; at the same time, shooting a woman to death would be considered exotic in lndia, where firearms are not freely available and the prevalence of guns is viewed as an American phenomenon. ${ }^{36}$

We identify sexual violence in immigrant of color and Third World communities as cultural, while failing to recognize the cultural aspects of sexual violence affecting mainstream white women. This is related to the general failure to look at the behavior of white persons as cultural, ${ }^{37}$ while always ascribing the label of culture to the behavior of minority groups. ${ }^{38}$ Thus, to bolster her claim that we cannot embrace both feminism and the values of minority cultures, Okin invokes the recent $\mathrm{Ne}$ -

33. Rey Chow, Violence in the Other Country: China as Crisis, Spectacle, and Woman, in Third World Women and the Politics of Feminism 81, 84 (Chandra Talpade Mohanty ed., 1991).

34. Narayan, supra note 22, at 101.

35. ld. at 102.

36. Id.

37. In suggesting there is a general failure to look at the behavior of white persons as cultural, $\mathrm{l}$ am not asserting that actions are never attributed to whiteness. Clearly, this attribution occurs. But 1 would assert that behavior is more often attributed solely to race when the actor is a person of color. Differences among and between groups identified as white are more clearly visible in the popular imagination than are differences among and between groups of color. For example, behavior that would be understood as a purely "racial" phenomenon when engaged in by a person of color may be more readily conceptualized as a product of class status, or geographical region, when engaged in by someone who is white.

38. For another example, see Maureen O'Hagan, An Untraditional Death: Trial Bares Promise, Pitfalls of Arranged Marriage, Wash. Post, Aug. 29, 2000, at B1. The article's heading suggests that Viresh and Alpna Patel's arranged marriage-traditional in Indian cultures - was to blame for the stabbing to death of the husband. As a letter to the editor describes, this is analogous to calling the death of Nicole Brown Simpson a "pitfall of dating." Hemant A. Pradhan, An Arranged Marriage, Wash. Post, Sept. 5, 2000, at A24.

Geeta Patel suggests that we "reverse the gaze" as a strategy to combat the problematic generalizations that homogenize and create a distance between the reader and the "other." For example, she takes a paragraph from the New York Times on the abuse of women in India that reads: "In India's system of arranged marriages, the bride is often regarded as a source of dowry income and in some cases little more than a servant in her husband's family home." Geeta Patel, Killing the Other Off 5 (2001) (unpublished manuscript, on file with the Columbia Law Review). Suggesting we imagine this to be a story about the United States in the lndian media, Patel poses that we read it as follows: "In the U.S. system of marriages, the bride is often regarded as a source of income and is in some cases little more than a servant in her husband's home." This substitution facilitates the understanding that such a generic statement about all women in the United States devalues U.S. women in a frozen and static matter. Id. at 8. 
braska case of two sisters, thirteen and fourteen years of age, who were forced by their 1raqi immigrant father to marry twenty-eight and thirtyfour-year-old men. ${ }^{39}$ But why are only the child marriages of nonwhite immigrants and not those of white Christian sects believed to threaten feminism? Okin fails to discuss another well-publicized case that took place in a splinter Mormon sect in Utah, involving a sixteen-year-old forced by her father to marry her thirty-two-year-old uncle, as his fifteenth wife. ${ }^{40}$ The failure to see that not only racialized minority cultures conflict with feminist values reflects the habit of assuming people of color to be motivated by culture and white persons to be motivated by choice.

We can see this phenomenon in differential responses to women wearing the veil. Feminist theorist Homa Hoodfar reports interviewing a white Canadian woman who had converted to lslam and worn a veil for years. ${ }^{41}$ She had worked at a job for several months when she realized her coworkers did not know she was a Muslim. One day when she complained about the heat, a colleague suggested she remove her scarf. She answered that as a practicing Muslim she did not want to do that. At first her coworker did not believe her. When she insisted and asked others if they had ever seen her without the scarf, they replied no, but explained they thought she was following a fashion. Hoodfar contrasts this account with her own experience. Following a disastrous haircut, she wore a scarf for a few weeks. A student asked if she had taken up the veil, and said the class thought she had joined "them"-the "veiled women." As Hoodfar writes, when a white woman who is Muslim wears a veil, it is perceived as fashion; when an 1ranian-Canadian woman wears a scarf as fashion, it is perceived as a veil. ${ }^{42}$

What facilitates this failure to see the asymmetrical ascription of culture in motivating other communities' practices and our own? ${ }^{43}$ The ten-

39. See Okin, supra note 1 , at 18.

40. The girl's father pled guilty to felony child abuse for beating her into unconsciousness when she tried to run away; her uncle was sentenced to ten years in prison. For a discussion of this case, see Volpp, Blaming Culture, supra note 20, at 100-02. While the girl's uncle was not prosecuted under Utah's 104-year-old ban on plural marriage, the state is currently prosecuting a man named Tom Green, married to five women, in the state's first prosecution for polygamy in several decades. The district attorney decided to pursue the case after Green appeared on Jerry Springer, Judge Judy, and Dateline NBC to discuss his polygamous union. Pauline Arrillaga, Putting Polygamy on Trial in Utah: Crusade Against Practice Stirs Debate on Child Abuse and Religious Freedom, Wash. Post, Dec. 8, 2000, at A49.

41. Homa Hoodfar, The Veil in Their Minds and On Our Heads: Veiling Practices and Muslim Women, in The Politics of Culture in the Shadow of Capital 248, 270 (Lisa Lowe \& David Lloyd eds., 1997).

42. Id.

43. The insights of cognitive bias theory are helpful here. See Linda Hamilton Krieger, The Content of Our Categories: A Cognitive Bias Approach to Discrimination and Equal Employment Opportunity, 47 Stan. L. Rev. 1161, 1186-1211 (1995). As Hamilton Krieger explains, incoming information is processed through a lens that shapes how we understand that information. She describes a study where school age children were presented cartoonlike drawings of two children and a verbal description of the scene. 
sion believed to exist between feminism and multiculturalism, or universalism and cultural relativism, not only relies upon the assumption that minority cultures are more sexist, but also assumes that those cultures are frozen and static entities. Within these discourses, only minority cultures are considered traditional, and made up of unchanging and longstanding practices that warrant submission to cultural dictates. Non-western people are assumed to be governed by cultural dictates, whereas the capacity to reason is thought to characterize the West. ${ }^{44}$ There appears to be an inverse correlation between full citizenship and cultural visibility. ${ }^{45}$

One drawing showed two students sitting in a classroom, one behind the other. The verbal description was: "Mark was sitting at his desk, working on his social studies assignment, when David started poking him in the back with the eraser end of his pencil. Mark just kept on working. David kept poking bim for a while, and then he finally stopped." Id. at 1202 (citation omitted). When David was described as black, the subjects judged his behavior to be more mean and threatening and less playful and friendly than when David was described as white. Id. at 1202-03. Hamilton Krieger also writes that "once a behavior has been encoded as a trait, its effect on subsequent judgments increases over time. It then supports and validates the preexisting stereotypic expectancy." Id. at I203 (citation omitted). This reflects the causes we attribute to an event. Hamilton Krieger gives the example of two workers, one male and one female, who perform poorly on a stereotypically male task. Hamilton Krieger found that the employer attributes the failure by the female employee to stable causes associated with her gender, but attributes the failure by the male employee to transient, environmental causes. Id. at 1206.

44. For an example of this, one could turn to the Aleyamma Mathew case. Severely beaten over a period of many years, she left her husband several times and consulted a lawyer about getting a divorce. While it is not uncommon for battered women to repeatedly return to battering relationships, her return to her husband was explained as follows: "Despite it all-despite years of drunken threats and vicious beatings-Aleyamma had resolved once again to preserve the traditions of her ancestors and her homeland, whatever the personal cost." Parameswaran, supra note 25, at 83-84 (quoting the Dallas Observer). Thus, her motivation is described as exclusively cultural.

45. This is an important observation of anthropologist Renato Rosaldo. Renato Rosaldo, Culture and Truth: The Remaking of Social Analysis 198 (1989). Anthropology, the discipline principally concerned with culture, has well-documented colonial origins, that developed to assist in managing the problem of ruling others. See Talal Asad, Introduction to Antbropology and the Colonial Encounter 9, 14-19 (Talal Asad ed., 1973). In the words of Claude Lévi-Strauss:

Anthropology is not a dispassionate science like astronomy, which springs from the contemplation of things at a distance. It is the outcome of a historical process which has inade the larger part of mankind subservient to the other, and during which millions of innocent human beings have had their resources plundered and their institutions and beliefs destroyed, whilst they themselves were ruthlessly killed, thrown into bondage, and contaminated by diseases they were unable to resist. Anthropology is daughter to this era of violence: its capacity to assess more objectively the facts pertaining to the human condition reflects, on the epistemological level, a state of affairs in which 1 part of mankind treated the other as an object.

Claude Lévi-Strauss, Anthropology: lts Achievements and Future, 7 Current Anthropology 124, 126 (1966).

Scholars like Rosaldo, George Marcus, and James Clifford have successfully developed a critical anthropology that departs from this history. See James Clifford, The Predicament of Culture: Twentieth-Century Ethnography, Literature, and Art 5-7 (1988); James 
Those with power appear to have no culture; those without power are culturally endowed. Western subjects are defined by their abilities to make choices, in contrast to Third World subjects, who are defined by their group-based determinism. ${ }^{46}$ Because the Western definition of what makes one human depends on the notion of agency and the ability to make rational choices, to thrust some communities into a world where their actions are determined only by culture is deeply dehumanizing. ${ }^{47}$

These assumptions preclude the understanding that minority cultures, like all cultures, undergo constant transformation and reshaping. ${ }^{48}$ What is also forgotten about culture in this bifurcated discourse is that culture and claims to cultural identity are always contested within communities. ${ }^{49}$ Culture is constantly negotiated and is multiple and contradictory. The culture we experience within a particular community will be specific and affected by our age, gender, class, race, disability status, and sexual orientation. The "culture" Okin assumes must be recognized through multiculturalism is comprised primarily of male articulations of gender-subordinating values. But minority cultures encompass feminist

Clifford, Introduction to Writing Culture: The Poetics and Politics of Ethnography 1, 8-13 (James Clifford \& George E. Marcus eds., 1986).

46. Identities are consolidated by excluding behaviors deemed abhorrent. Anne McClintock suggests that abjection-expelling, casting out or away-has served as a formative aspect of modern industrial imperialism. Certain groups are expelled and obliged to inhabit the edges of modernity, as slaves, prostitutes, the colonized, domestic workers, and the insane. Anne McClintock, Imperial Leather: Race, Gender and Sexuality in the Colonial Contest 71-72 (1995). One could argue that immigrants of color figure in the American imagination as an abject community-obliged to inhabit the edges of modernity through the signification of immigrant culture as a harbinger of what society thinks it must reject. African Americans certainly experience abjection whereby Americans continually project their problems onto the African-American community-for example, concerns about teen pregnancy, violence, criminality, and poverty.

47. I have written elsewhere about the depoliticizing effects of cultural discourse. See Volpp, Blaming Culture, supra note 20, at 96-97. For a description of other work in this vein, see Charles L. Briggs \& Carla Mantini-Briggs, "Bad Mothers" and the Threat to Civil Society: Race, Cultural Reasoning, and the Institutionalization of Social Inequality in a Venezuelan Infanticide Trial, 25 Law \& Soc. Inquiry 299, 299-302 (2000). The authors describe both their own work on public health officials who blame high morbidity and mortality from cholera on cultural practices, thereby deflecting charges of institutional corruption, inefficiency, indifference, and genocide, and the work of Paul Farmer, who has suggested that epidemiologists and public health officials conflate structural violence against poor populations with cultural difference. Id. at 303.

48. See generally Stuart Hall, Cultural ldentity and Diaspora, in Identity, Community, Culture, Difference 222, 225 (Jonathan Rutherford ed., 1990) (asserting that cultural identities undergo constant transformation through the play of history and power, rather than being eternally fixed in some essentialized past).

49. For a strong criticism of academic writing for its failure to acknowledge the contestation of culture within the Middle East, see Ann Elizabeth Mayer, A "Benign" Apartbeid: How Gender Apartheid Has Been Rationalized, 5 UCLA J. Int'l L. \& Foreign Aff. 237, 291-319 (Fall, 2000/Winter, 2001) (asserting that failure to recognize conflict within Middle Eastern countries as to women's rights creates a dichotomy between a Middle Eastern world of believing Muslims and a Western, secular world forcing Western human rights on the Middle East). 
values as well. Recognizing that feminism exists within communities of color breaks down the equation between multiculturalism and antifeminism inherent in the notion of "feminism versus multiculturalism." (This equation breaks down as well when we realize that gender-subordinating values are also valued in the dominant culture of the West) ${ }^{50}$

The manner in which culture is hybrid and contested is often not recognized. ${ }^{51}$ This happens, in part, because people within a community will explain their actions through their cultural identity. ${ }^{52}$ Alternatively, people outside a particular community may mistakenly identify certain practices within that community as the result of culture. ${ }^{53}$ Often these two occur in tandem, so that, for example, a criminal defendant will invoke "culture" as the explanation for his sex-subordinating behavior. ${ }^{54}$ The perspective of women within that community who would reject such a claim is generally ignored. The media happily picks up the defendant's claim (or proffers its own claim) that this problematic behavior is a product of a certain community's culture, since the idea that nonwhite others

50. Whether it makes more sense to make the claim that gender subordination is not part of any culture, or that gender subordination is fundamental to every culture, depends on whether the speaker seeks, in the first instance, to make an aspirational claim, or in the second, to demonstrate the universality of this problem.

51. As Maivân Lâm points out, a culture is not a cult. She writes:

[1]mpulses for change exist in any cultural community precisely because a culture, unlike a cult, is not built around uniform values and limited interests but rather accommodates an ongoing adjustment of the wide-ranging and sometimes conflicting needs and desires [of] the many individuals and groups of the community.

Lâm, supra note 14, at 12.

52. For example, heads of Asian nations claim that freedom and democracy are not "Asian values." For a critical response to this claim, see Amartya Sen, Human Rights and Asian Values, The New Republic, July 14 \& 21, 1997, at 33. As Bonnie Honig points out, when men or states claim that "my culture made me do it" they are claiming a kind of privacy or privilege that must be resisted for the sake of both human rights and "culture." Honig, supra note 1 , at 36 . These kinds of claims rely on just as static a vision of culture as that represented by outside observers condemning "other" cultures, and allow community and national elites to benefit. 1n making this observation about how elites can construct culture for their own benefit, I should not be understood to be saying culture is meaningless, or that it does not matter.

53. See, for example, the claim of Samuel Huntington that the East does not embrace Western political values where Huntington warns that this will engender a "clash-ofcivilizations." Samuel Huntington, The Clash of Civilizations and the Remaking of the World Order 20-21 (1996). For a critical response to this claim, see Aihwa Ong, Flexible Citizenship: The Cultural Logics of Transnationality 185-213 (1999). Huntington and Lawrence Harrison have just released a new volume examining the relationship between "culture" and "progress." Culture Matters: How Values Shape Human Progress (Lawrence E. Harrison \& Samuel P. Huntington, eds. 2000).

54. On "cultural defenses," see generally Leti Volpp, Talking "Culture": Gender, Race, Nation, and the Politics of Multiculturalism, 96 Colum. L. Rev. 1573, 1575-76 (1996) (analyzing the broader theoretical context of attempts to bar the use of "cultural defenses"). 
engage in primitive and misogynistic cultural practices fits already existing conceptions. ${ }^{55}$

Unfortunately, the "culture" targeted in the feminism versus multiculturalism debate is often an indiscriminate lumping of self-serving claims by elites of communities or nations, ${ }^{56}$ the claims of anthropologists that are truly relativistic, ${ }^{57}$ and the claims of those who, from a feminist

55. For the claim that such depictions serve to primitivize the inhabitants of Pacific Rim nations, disciplining the chief competitors of the United States in the global economy by engaging in a displaced "Asian-bashing," see Kristin Koptiuch, "Cultural Defense" and Criminological Displacements: Gender, Race and (Trans) Nation in the Legal Surveillance of U.S. Diaspora Asians, in Displacement, Diaspora, and Geographies of Identity 215, 223 (Smadar Lavie \& Ted Swedenburg eds., 1996).

56. For further discussion on how this transpires in the "Asian values" debate, see Karen Engle, Culture and Human Rights: The Asian Values Debate in Context, 32 N.Y.U. J. Int'l L. \& Pol. 291, 314-16 (2000).

57. Into this group I would put the work of Richard Shweder. See infra note 127. What is troubling is that this kind of work becomes caricatured. For an example of this, I would point to Martha Nussbaum's description of a conference where a French anthropologist:

expresses regret that the introduction of smallpox vaccination to India by the British eradicated the cult of Sittala Devi, the goddess to whom one used to pray to avert smallpox. Here, she says, is another example of Western neglect of difference. Someone (it might have been me) objects that it is surely better to be healthy rather than ill, to live rather than to die. The answer comes back; Western essentialist medicine conceives of things in terms of binary oppositions: life is opposed to death, health to disease. But if we cast away this binary way of thinking, we will begin to comprehend the otherness of Indian traditions.

Martha Nussbaum, Sex and Social Justice 35 (1999).

Nussbaum describes the arguments of the French anthropologist so that they sound quite ludicrous, but nevertheless, still positions them as a serious target of criticism. One question is whether ludicrous-sounding arguments in favor of relativism are really the best target of Nussbaum's criticism. The other question is whether this description of the introduction of smallpox vaccination actually captures the coercion and resistance that occurred, apparent in a description of the campaign in a village of the Ho tribe in the Indian state of Bihar:

In the middle of the gentle Indian night, an intruder burst through the bamboo door of the simple adobe hut. He was a government vaccinator, under orders to break resistance against smallpox vaccination. Lakshmi Singh awoke screaming and scrambled to hide herself. Her husband leaped out of bed, grabbed an axe, and chased the intruder into the courtyard. Outside a squad of doctors and policemen quickly overpowered Mohan Singh. The instant he was pinned to the ground, a second vaccinator jabbed smallpox vaccine into his arm. . . The government team held him until they had injected enough vaccine. . . the rest of the team overpowered the entire family and vaccinated each in turn. Lakshmi Singh bit deep into one doctor's hand, but to no avail.

Dipesh Chakrabarty, Provincializing Europe: Postcolonial Thought and Historical Difference $44(2000)$ (quoting Lawrence Brilliant with Girija Brilliant, Death for a Killer Disease, Quest, May/June 1978, at 3). The reason for this resistance to the vaccine was not apparent to me, until I read the remainder of Lawrence Brilliant's narrative in another source, which described Mohan Singh offering the doctor, who his wife had bitten, the single ripe cucumber left in his small vegetable plot. Mohan Singh then explained:

My dharma [ ] is to surrender to God's will. Only Crod can decide who gets sickness and who does not. . . We must resist your needles. ... We have done 
perspective, seek to explain that minority and Third World women should be understood as more than victims of their culture. This problematic aggregation of very different assertions about culture has forestalled constructive discussion.

\section{The Theories That Bind}

The assumption that women are by definition more oppressed in minority cultures can be traced to several theoretical bases: the history of colonialism, depictions of the feminist subject, the limits of liberalism, and the use of binary logic. While I discuss these intellectual genealogies separately, they are constitutive of one another.

There are historical antecedents for the claim that minority communities are more patriarchal than those of the liberal West. Orientalism's binary juxtaposition of a "traditional" East with a "modern" West-the theoretical engine of colonialism-was premised in part on perceptions of non-Western women as oppressed subjects. Orientalism associated the East with ancient ritual, despotism, and barbarity ${ }^{58}$ and the West with pro-

our duty. We can be proud of being firm in our faith. ... Daily you have come and told tne it is your dharma to prevent this disease with your needles. . . . Tonight you have used force. You say you act in accordance with your duty. I have acted in accordance with mine. It is over. God will decide. Now I find you are guests in my house. It is my duty to feed guests. I have little to offer at this time. Except this cucumber.

Lawrence Brilliant, Stories of the Spirit, Stories of the Heart: Parables of the Spiritual Path from Around the World I54 (Christina Feldman \& Jack Kornfield ed., I99I).

I excerpt these three passages here because they raise questions about how difference is presented. Nussbaum's description flattens difference, so that difference is voiced by a silly-sounding relativistic French anthropologist. Chakrabarty's excerpt suggests that eradication of difference has been accompanied by force. And Brilliant's description paints in the picture of why this family chose to assert their difference. The reaction of the reader to these three depictions of the introduction of the smallpox vaccination will, I wager, be completely different.

58. Lest anyone think that these dynamics are a thing of the past, I would point to the Southern Baptist Convention prayer booklets, published by tbe International Mission Board to encourage their members to pray for Hindus, Jews, Buddhists, and Muslims. Almost I6 million Americans are Southern Baptists. The book of Prayer for Hindus states:

More than 900 million people are lost in the hopeless darkness of Hinduism, worshiping 330 million gods and goddesses created by the imagination of men and women searching for a source of truth and strength. ... Walking the streets of India during Divali is a sobering reminder of the power of darkness that lies over tbis land. . . Mumbai is a city of spiritual darkness. Eight out of every 10 people are Hindu, slaves bound by fear and tradition to false gods and goddesses ... Please pray that the educated computer engineers who have many contacts with Christians will be open to the truth.

International Mission Board, Divali: Festival of Ligbts: Prayer for Hindus 2, 3, 5,9 (1999), available at http://www.hindunet.org/HPG.pdf; see also Hanna Rosin, Southern Baptists, Expanding Effort, Target Hindus for Conversion, Wash. Post, Oct. 2I, 1999, at A19 (describing efforts by Baptists to convert Hindus). 
gress, democracy, and civilization. ${ }^{59}$ Modernity was constructed as a corrective to tradition. ${ }^{60}$ The status of women was considered a benchmark of modernity. Thus, the colonialist writer, James Mill, wrote in 1840 that a culture could be judged by the way it treats its women. ${ }^{61}$ lmproving the position of women was a component of the civilizing process, along with the rule of law, education, and Christianity. For example, British colonial officials in Egypt specifically invoked the veil and treatment of women under Islam as a justification for colonialism. ${ }^{62}$

British suffragists, in turn, used the image of what they saw as "victimized 'sisters'" in India to bolster their arguments for expanding the category of British "citizen" to include themselves. ${ }^{63}$ They invoked both racial superiority and national pride in distinguishing themselves from colonized women. ${ }^{64}$ The image of these "victimized sisters" provided an example of submission that symbolized what these suffragists were fighting against and what they did not wish to be: immobile, secluded in the home, and without rights in the public arena. ${ }^{65}$ Thus, the woman of the

59. See generally Edward Said, Orientalism 1-4 (1978) (examining Western depictions of the Orient as the other). Note that in presenting this simple, bifurcated description, 1 do not intend to suggest that this was not a hybrid, contradictory process that varied across time and space. For a study of the heterogeneity of Orientalism, see generally Lisa Lowe, Critical Terrains: French and British Orientalisms 1-29 (1991) (examining multiple discourses of orientalism).

60. See Said, supra note 59, at 8-9 (describing Orientalist project of instructing the Orient "in the ways of the modern West").

61. See Uma Chakravarti, Whatever Happened to the Vedic Dasi? Orientalism, Nationalism and a Script for the Past, in Recasting Women: Essays in Indian Colonial History 27, 35 (Kumkum Sangari \& Sudesh Vaid eds., 1990) (discussing Mill).

62. See Leila Ahmed, Women and Gender in Islam: Historical Roots of a Modern Debate 152-53 (1992). The British consul general, vociferous in making these claims, was, ironically enough, a founding member of the Men's League for Opposing Women's Suffrage in England. See id. at 153. Marnia Lazreg also writes that even while the "condition of women" in the colonies was used to justify colonial rule, French men showed contempt for Algerian women whom they considered imınoral (even while colonialism contributed to a flourishing of prostitution). Marnia Lazreg, The Eloquence of Silence: Algerian Women in Question 58 (1994).

63. Inderpal Grewal, Home and Harem: Nation, Gender, Empire and the Culture of Travel 11 (1996) [hereinafter Grewal, Home and Harem].

64. See id. at 65. Inderpal Grewal argues that Englishwomen's rights to vote and to equality were "made through and against the discourse of the confinement of colonized women, and within the view of nation as empire...." Id. at 67. Englishwoinen appealed to national and racial superiority in arguing that denying the right to vote and other rights to Englishwomen threatened the status of England as a "civilized" nation, in contrast to "uncivilized" regions of the world. ld. For most of these women, being part of an empire "gave them a sense of racial superiority that enabled them to feel their own worth and equality with men." ld. at 66.

65. Id. at 66-67. That these women appeared to engage in sexual practices considered immoral under Christianity was also used to justify colonial rule. As Martin Chanock notes, judgments about the sexual behavior of people colonized by Europe-for example, the existence of harems, lobolo, and sexually explicit Hindu art-suggested that promiscuity was at the core of other cultures; a matter of some horror to those who defined themselves through chastity. Martin Chanock, 'Culture' and Human Rights: 
East became a crucial symbol in British feminists' struggle for suffrage. ${ }^{66}$ As has been documented, this struggle took place in a context where Western women appeared unaware of the parallels between the conditions they criticized and the conditions under which they themselves lived. This included a lack of physical freedom and an economic dependence on husbands. ${ }^{67}$

The particular relationship between women and national identity was not solely constructed by the West. Rather, nationalist discourse used in various anticolonial struggles relied upon the figure of women to strengthen notions of culture and tradition. ${ }^{68}$ The regulation of women and their sexuality has often stood in for national culture. ${ }^{69}$ The fusing of gender with culture and tradition continues when the space of the "home" and practices within it provide an oasis of secure identity for com-

Orientalising, Occidentalising and Authenticity, in Beyond Rights Talk and Culture Talk: Comparative Essays on the Politics of Rights and Culture 15, 20 (Mahmood Mamdani ed., 2000).

66. See Antoinette Burton, Burdens of History: British Feminists, Indian Women, and Imperial Culture, 1865-1915, at 8-12 (1994).

67. See Leslie A. Flemming, A New Humanity: American Missionaries' Ideals for Women in North India, 1870-1930, in Western Women and Imperialism: Complicity and Resistance 191, 195 (Nupur Chaudhuri \& Margaret Strobel eds., 1992); see also Grewal, Home and Harem, supra note 63, at 73 (describing how attitudes toward "native" women worked in some instances to disguise oppressive conditions for women in Englandespecially working-class women); Mervat Hatem, Through Each Other's Eyes: The Impact on the Colonial Encounter of the Images of Egyptian, Levantine-Egyptian, and European Women, 1862-1920, in Western Women and Imperialism, supra, at 35, 37 (asserting that Western women could "avoid confronting their own powerlessness" by "thinking of themselves as all powerful and free vis-a-vis Egyptian women"); Janaki Nair, Uncovering the Zenana: Visions of Indian Womanhood in Englishwomen's Writings, 1813-1940, $2 \mathrm{~J}$. of Women's History 8, 25 (1990) (arguing that “[b]y making 'visible' the woman of the colonies, [British women] could successfully make 'invisible' their own colonisation by English men").

68. See Partha Chatterjee, The Nation and its Fragments: Colonial and Postcolonial Histories 116-57 (1993). Chatterjee describes how, for Indian nationalists, the material realm corresponded to the outside world and the spiritual realm to the home, so that in the face of colonial domination, the home and women were to be the main site of preserving national culture. Id. at 126 . Chatterjee notes that the ideal of the woman constructed through nationalism was differentiated simultaneously from Westernized women and from working-class Indian women. Id. at 127. Margaret Keck and Kathryn Sikkink describe a similar pattern in Kenya whereby anticolonial leaders like Jomo Kenyatta held up an idealized version of the traditional past as an alternative to Western "progress" that was inappropriate for the Kenyan context. This version focused on Western missionary attempts to eradicate female circumcision, cementing together national control of women and their sexuality with the fight against colonialism. Margaret E. Keck \& Kathryn Sikkink, Activists Beyond Borders: Advocacy Networks in International Politics 69-72 (1998).

69. See Gayatri Gopinath, Nostalgia, Desire, Diaspora: South Asian Sexualities in Motion, 5 Positions 467, 468 (1997); Nira Yuval-Davis, Gender \& Nation 22-23 (1997). 
munities experiencing dislocation or subordination..$^{70}$ Thus, traditional identity is often conflated with women's dress, behavior, and role in both immigrant communities facing hostility ${ }^{71}$ and Third World communities suffering economic insecurity from the demands of globalization. ${ }^{72}$ lmages of nations and cultures are constructed in metaphors that situate women in marking the identity of the nation. ${ }^{73}$

The relative status of women across communities is still used to assess the progress of culture. And the discourse of feminism versus multiculturalism assumes that women in minority communities require liberation into the "progressive" social customs of the West. The idea that "other" women are subjected to extreme patriarchy is developed in relation to the vision of Western women as secular, liberated, and in total control of their lives. But the assumption that Western women enjoy complete liberation is not grounded in material reality. Rather, Western women's liberation is a product of discursive self-representation, whicb contrasts

70. See Narayan, supra note 22, at 27 (using example of dress to assert that men in the Third World seem to be permitted a greater degree of cultural latitude than women and are less frequently accused of "Westernization").

71. See Vijay Prashad, The Karma of Brown Folk 122-23 (2000). As Prashad writes, migrants are under enormous pressure to assimilate into a presumptively homogenous United States, but they find a forbidding racism, as well as a bifurcation between South Asian tradition and U.S. modernity, disregarding the imbrication of the two domains as well as the dynamic of global capital. This leads in at least two directions: either into the shell of "national culture," or to an intensified desire to assimilate and gain acceptance. Id.; see also Anannya Bhattacharjee, The Habit of Ex-Nomination: Nation, Woman, and the Indian Immigrant Bourgeoisie, 5 Pub. Culture 19, 27-32 (1992) (describing the role of women in shoring up national identity among Indian immigrants).

72. See L. Amede Obiora, Feminisin, Globalization, and Culture: After Beijing, 4 Ind. J. Global Legal Stud. 355, 380-81 (1997). Although Obiora does not specifically link the sedimentation of culture with gender in this description, she does note that "[m]arginalized by exposure to an onslaught of conditions of modernity, the market economy, and imperialistic transnational enterprises, distinct cultural groups tend to view themselves as being under pressure to demonstrate their ritual purity and allegiance to traditional high culture." Id,; see also Joel Richard Paul, Cultural Resistance to Global Governance, 22 Mich. J. Int'l L. (forthcoming 2001) (manuscript at 16-25, on file with the Columbia Law Review) (arguing that when states regulate women they reaffirm their sovereignty through social controls without hindering globalization).

73. McClintock, supra note 46, at 354-57. An example that demonstrates how women's bodies are used to mark national identity is the mass rape of women by men as part of a policy of "ethnic cleansing." Such use of rape has occurred in the recent past in Rwanda and the former Yugoslavia. Beth Stephens, Humanitarian Law and Gender Violence: An End to Centuries of Neglect? 3 Hofs. L. \& Pol'y Symp. 87, 91-92 (1999) (describing rape as an instrument of ethnic cleansing in Bosnia-Herzogovenia, Croatia, and Rwanda). It is estimated that between 200,000 and 400,000 women were raped in Bangladesh in 1971 in the war between Pakistan and Bangladesh. Heidi A. Chesley, Book Note, Freedom from Violence: Women's Strategies from Around the World, 16 Harv. Women's L.J. 303, 306 (1993) (reviewing Legal Literacy: A Tool for Women's Empowerment (Margaret Schuler ed., 1992)); see generally Fionnuala Ni Aolain, The Entrenchment of Systematic Abuse: Mass Rape in Former Yugoslavia, 8 Harv. Hum. Rts. J. 285, 285-87 (1995) (reviewing Mass Rape: The War Against Women in Former Yugoslavia (Alexandra Stiglmayer ed., 1994)). 
Western women's enlightenment with the suffering of the "Third World woman."74

The relativistic linking of differences between women is also a legacy of certain variants of feminism, which espoused a unitary female subject. ${ }^{75}$ This unitary female subject was developed through asserting the existence of gender-based subordination oppressing all women across time and space. ${ }^{76}$ Sex differences were privileged over any other form of oppression, such as poverty and racism, ignoring the contexts that differentially shape a woman's experience. ${ }^{77}$ These differences of sex have frequently been equated with sexual violence, which has been used to demonstrate, and often to define, women's oppression by men. ${ }^{78}$ While, as feminist theorist lnderpal Grewal suggests, "it is necessary to understand gender as a highly contingent and diverse formation," 79 the assumption in the discourse of feminism versus multiculturalism is that women can live their lives only as women, rather than as parts of other communities, so that their subjectivity is constructed only by gender. ${ }^{80}$

What this presumed universality elides can be illustrated in the context of women experiencing violence in the United States. For example,

74. See generally Chandra Talpade Mohanty, Under Western Eyes: Feminist Scholarship and Colonial Discourses, in Third World Women and the Politics of Feminism 51 (Chandra T. Mohanty et al. eds., 1991) (criticizing Western feminist depictions of Third World women).

75. It should be clear here that in describing this genealogy I understand feminism to be and to have been complex, multivalent, and contradictory. 1 am describing here certain strands within feminism and not all feminist theory.

76. For an example of the feminist theory that 1 am describing, see generally Mary Daly, Gyn/Ecology: The Metaethics of Radical Feminism 109-12 (1978) (positing universal woman characterized by male violence against her in the form of witch burning, sati, footbinding, and "female genital mutilation").

77. As Teresa de Lauretis writes: "To pose the question of gender as arising from a fundamental sexual difference between men and women has the effect of universalizing gender opposition, and makes it impossible to articulate differences among and within women." Teresa de Lauretis, Technologies of Gender: Essays on Theory, Film, and Fiction 1 (1987).

78. See Inderpal Grewal, On the New Global Feminism and the Family of Nations: Dilemmas of Transnational Feminist Practice, in Talking Visions: Multicultural Feminism in a Transnational Age 501, 515, 519 (Ella Shohat ed., 1998) [hereinafter Grewal, On the New Global Feminism] (criticizing prominence given to cases of domestic violence and rape that overshadow any other issue as site of feminist activism).

79. Grewal, Women's Rights, supra note 19, at 342.

80. See Inderpal Grewal, On the New Global Feminism, supra note 78, at 519-20; Norma Alarcón, The Theoretical Subject(s) of This Bridge Called My Back and AngloAmerican Feminism, in Making Face, Making Soul: Haciendo Caras 356 (Gloria Anzaldúa ed., 1990). As Alarcón writes:

The inclusion of other analytical categories such as race and class becomes impossible for a subject whose consciousness refuses to acknowledge that "one becomes a woman" in ways that are much more complex than in a simple opposition to men. In cultures in which "asymmetric race and class relations are a central organizing principle of society," one may also "become a woman" in opposition to other women.

Id. at 360. 
immigrant identity has affected women's access to services, because some battered women's shelters will not house women with various immigration statuses, or will not serve women who do not speak English. ${ }^{81}$ The immigration laws of the United States have also detrimentally shaped the experiences of women who suffer domestic violence. For example, the I986 Immigration Marriage Fraud Amendments ("IMFA") ${ }^{82}$ gave batterers additional tools with which they could threaten their immigrant spouses, ${ }^{83}$ until, after much documentation of this problem by activists, Congress created mechanisms battered women could use to negotiate around the traps created by IMFA. ${ }^{84}$ Lastly, rape in the U.S. context cannot be discussed without acknowledging the predominant paradigm of the white female victim that has shaped police, prosecutorial, and community responses. ${ }^{85}$ Thus, even while rape and domestic violence may be asserted as universal problems, these problems are shaped differently by forces such as race and immigration status, even within the context of the United States. The difficulties posed by such a use of the category "woman" have been extensively addressed. ${ }^{86}$ Yet, this unitary female subject

8I. Kimberle Crenshaw, Mapping the Margins: Intersectionality, Identity Politics, and Violence Against Women of Color, 43 Stan. L. Rev. I241, I249 (1991) [hereinafter Crenshaw, Mapping the Margins].

82. Immigration Marriage Fraud Amendments, 8 U.S.C. § II $86 a$ (2000).

83. Linda Kelly, Stories From the Front: Seeking Refuge for Battered Immigrants in the Violence Against Women Act, 92 Nw. U. L. Rev. 665, 669-71 (1998) (describing detrimental impact of IMFA on battered immigrant women). Driven by concerns about marriage fraud, IMFA created a two-year period of "conditional residence" for immigrant spouses married for less than two years. In order to secure permanent residency for an immigrant spouse, the petitioning spouse was required to complete the initial petition, attend a preliminary interview, after the two-year period sign and complete a petition in order to remove the conditions on residency, and attend any subsequent interview. The threat not to complete any of these requirements was used by batterers to dissuade battered spouses from reporting battery to the police or from pressing charges. Id.

84. Campaigns by activists led to legislative changes that attempt to ameliorate the abuse of power facilitated by conditional residency status and its petitioning requirements. These include the battered spouse waiver and VAWA's creation of self-petitioning for battered women so that they no longer require their batterers to sponsor them for residency. See Leti Volpp, Working with Battered Immigrant Women: A Handbook to Make Services Accessible 37-47 (1995) (on file with the Columbia Law Review) (describing how to assist clients in filing a waiver or petition).

85. See Crenshaw, Mapping the Margins, supra note 81, at 1266-82. "A study of rape dispositions in Dallas, for example, showed that the average prison term for a man convicted of raping a Black woman was two years, as compared to five years for the rape of a Latina and ten years for the rape of an Anglo woman." Id. at 1269; see generally Jennifer Wriggins, Rape, Racism, and the Law, 6 Harv. Women's L.J. 103, 104-13 (1983) (describing origins and implications of racism in modern attitudes toward rape).

86. For an examination of the limits of gender as a category of analysis when applied to the experiences of women of color, see Alarcón, supra note 80, at 354-56; Kimberlé Crenshaw, Demarginalizing the Intersection of Race and Sex: A Black Feminist Critique of Antidiscrimination Doctrine, Feminist Theory and Antiracist Politics, 1989 U. Chi. Legal F. 139, 139-40 (1989) [hereinafter Crenshaw, Demarginalizing the Intersection]; Angela P. Harris, Race and Essentialism in Feminist Legal Theory, 42 Stan. L. Rev. 581, 585-90 (1990); Celina Romany, Ain't I a Feminist? 4 Yale J.L. \& Feminism 23, 23-24 (1991). 
continues to be used in the feminism versus multiculturalism discourse, as well as in the discourse of transnational feminism that supports the struggle for "women's rights as human rights."

The idea that minority women suffer from their minority cultures also reflects the liberal ideals foundational to the discourse of feminism versus multiculturalism. Liberalism presumes an abstract subject standing separate and apart from the particular and local. ${ }^{87}$ But to set up the boundaries of the liberal subject as "human, civilized and universal," colonial discourse "inscribed the history of its others as backward and traditional, and thereby placed cultures of different kinds in a teleological and chronological ordering of history." 88 These others were displaced into "anachronistic space." ${ }^{9}$ Colonized people were considered not to inhabit history but to exist in a permanently anterior time, as living embodiments of the "archaic primitive." 90 Those positioned as the "other" continue to bear the disproportionate burden of difference, so that women of color or Third World women stand at the periphery of calls for global sisterhood. ${ }^{91}$ Thus, to be a rights-bearing liberal subject one must shed the burden of difference, as Okin suggests in her call for women to be the compliant subjects of assimilation and to leave their minority cultures. ${ }^{92}$

Lastly, the feminism versus multiculturalism discourse is premised in a binary logic that parallels the limitations created by structuring cultural relativism and universalism as irreconcilable. In the feminism versus multiculturalism discourse, "gender" and "race" are portrayed as oppositional, and thus mutually exclusive. The separation of gender and race in this fashion reflects the use of a reductive framework that has been widely

87. See Austin Sarat \& Roger Berkowitz, Disorderly Differences: Recognition, Accommodation, and American Law, 6 Yale J.L. \& Human. 285, 310 (1994) ("For liberals, the recognition of difference is . . inevitably a recognition of danger.").

88. Meyda Yegenoglu, Colonial Fantasies: Towards a Feminist Reading of Orientalism 95 (1998); see also David Lloyd, Race Under Representation, 13 Oxford Literary Rev. 63, 69 (1991) (describing project of Enlightenment as by-product of intersection of liberal humanism with necessities of imperial polity).

89. McClintock, supra note 46 , at 30 .

90. Id. For example, Hegel figured Africa as inhabiting not simply a different geographical space, but a different timezone, abandoned in prehistory before reason manifested in society. 1d. at 40-41; see generally Johannes Fabian, Time and the Work of Anthropology 73 (1991) (describing how anthropology constructed its object of study as distinguished from the West both in space and in time).

91. M. Jacqui Alexander \& Chandra Talpade Mohanty, Introduction: Genealogies, Legacies, Movements, in Feminist Genealogies, Colonial Legacies, Democratic Futures xiii, xviii-xix (M. Jacqui Alexander \& Chandra Talpade Mohanty eds., 1998).

92. Bonnie Honig points out an irony here, suggesting that Okin's liberal approach to gender subordination seems to contradict the group-based methodology through which women have sought power. As she writes, liberalism's "relentless individualism" supports a privatizing conception of citizenship that stands in some tension to the feminist idea of empowering women to act in concert to advance their own aims. Honig, supra note 1, at 39. 
criticized. ${ }^{93}$ Opposing race with gender suggests that women of coior may be better off if their cultures wither or become extinct. Women of color will still be women; they just will not have a cultural identity anymore. This suggestion relies upon two assumptions. First, it assumes that women of color gain nothing from their cultures-that cultures of color are largely oppressive ${ }^{94}$ and should be shed to eradicate gendered subordination. ${ }^{95}$ Second, the suggestion ignores the fact that race and gender are mutually constitutive of one another; one cannot simply separate them in this fashion. Vectors of identity cannot be analyzed as isolated phenomena. ${ }^{96}$

93. See, e.g., Paulette M. Caldwell, A Hair Piece: Perspectives on the Intersection of Race and Gender, 1991 Duke L.J. 365, 374 (criticizing separation of race and gender as not addressing experiences of those who live at intersection of interlocking forms of oppression); Crenshaw, Demarginalizing the Intersection, supra note 86, at 139 (same); Crenshaw, Mapping the Margins, supra note 81, at I244 (same); Harris, supra note 86, at 585-86, (same); Romany, supra note 86 , at 29 (same).

94. As Celestine Nyamu points out, culture can play a positive role in the pursuit of gender equality. She discusses the context of property relations in Kenya, where the language of customary rights to land has been the only defense to challenge the trend of marketization of land, implemented through formal law, that holds dangers for women's unregistered interests. Celestine I. Nyamu, How Should Human Rights and Development Respond to Cultural Legitimization of Gender Hierarchy in Developing Countries?, 4I Harv. Int'l L.J. 381, 406-09 (2000). As Lisa Lowe remarks, cultures can be emancipatory: "Some cultural forms succeed in making it possible to live and inhabit alternatives," and some "permit us to imagine what we have still yet to live." Lisa Lowe, Immigrant Acts: On Asian American Cultural Politics x (1996).

95. For a criticism of the desire that people shed their culture, see Avery Gordon \& Christopher Newfield, White Philosophy, 20 Critical Inquiry 737 (1994). Gordon and Newfield criticize the idea that:

Free of cultural identity, we will be able to treat people as people rather than as races. This ideal has strong appeal. . . . [but this assumes that] our dealings with one another can ignore the conflicts and coercions, the innumerable interdependent historical circumstances that make us who we are in the first place.

Id. at 742.

96. A number of scholars, such as Kimberle Crenshaw, insist that race and gender cannot be separated into opposing camps, for doing so denies the existence of women of color and the particularities of the subordination they face. More recently, Darren Hutchinson, Peter Kwan, and Frank Valdes have made new theoretical interventions in an attempt to describe accurately the manner in which subordination of sexism, racism, and homophobia interrelate, creating terms such as multidimensionality and cosynthesis. See, e.g., Darren Lenard Hutchinson, "Gay Rights" for "Gay Whites"?: Race, Sexual Identity, and Equal Protection Discourse, 85 Cornell L. Rev. 1358, 1362-68 (2000) (asserting theory of multidimensionality that describes synergistic relationship of race, gender, class, and sexuality); Peter Kwan, Jeffrey Dahmer and the Cosynthesis of Categories, 48 Hastings L.J. 1257, 1280-92 (1997) (discussing cosynthesis of race, gender, and sexuality so that each category is co-operationally constitutive); Francisco Valdes, Beyond Sexual Orientation in Queer Legal Theory: Majoritarianism, Multidimensionality, and Responsibility in Social Justice Scholarship or Legal Scholars as Cultural Warriors, 75 Denv. U. L. Rev. 1409, 1419-24 (1998) (discussing intersectionality, multiplicity, multidimensionality and queerness as challenges to unidimensional analysis). 
In this discourse feminism also stands for "rights," and multiculturalism stands for "culture." In the universalism/cultural relativism or feminism/multiculturalism debates, the values of Western liberalism are reified, defined as the opposite of culture. As has been asserted about the universalism/cultural relativism debate, what becomes codified are two falsely unified packages, one with "the stamp of human rights," and one without, each of which depends upon the other for its meaning and identity. ${ }^{97}$ With the discourse of feminism versus multiculturalism, each term is presumed to exclude the values of the other. Feminism is presumed not to value the rights of minority cultures; multiculturalism is presumed not to value the rights of women. Constructing feminism and multiculturalism as oppositional severely constricts how we think about difference.

A similar criticism has been made of the sameness/difference debate in feminist theory. In the sameness/difference debate, the standard that is reified is what is male. ${ }^{98}$ The only options for thinking about these problems then become: "Should they be like us?" or, "Should they be allowed to be different from us?" This has been called "an impossible choice." ${ }^{99}$ Either what is different to the masculinist standard is reimagined as the same, man's mirror image-or what is different is reduced to being man's other. ${ }^{100}$ One seeks either equal status, demand-

97. Arati Rao, The Politics of Gender and Culture in International Human Rights Discourse, in Women's Rights, Human Rights: International Feminist Perspectives 167, 168 (Julie Peters \& Andrea Wolper eds., 1995). Acceptance of this divide between universalism and cultural relativism characterizes the vast majority of legal scholarship on the issue. See, e.g., Tracy E. Higgins, Anti-Essentialism, Relativism, and Human Rights, 19 Harv. Women's L.J. 89, 92-97 (1996) (describing the challenge cultural relativism poses to feminism). While providing a thoughtful analysis, this work nonetheless theorizes about a difference that is presumed to exist because of this divide.

98. In noting the similarities between these bifurcated discourses, I follow the work of Dianne Otto who points out the dualism shared by the universalism/cultural relativism and the sameness/difference debate. Dianne Otto, Rethinking the "Universality" of Human Rights Law, 29 Colum. Hum. Rts. L. Rev. 1, 15-17 (1997). She makes the interesting claim that in the universalism/cultural relativism debate, the dualities deployed "by both sides of the debate furthers the interests of the elites of both camps rather than those of the non-elite majority." Id. at 7 .

99. Joan W. Scott, Deconstructing Equality-Versus-Difference: Or, the Use of Poststructuralist Theory for Feminism, 14 Feminist Stud. 33, 43 (1988).

100. This dynamic is illustrated by the problem of what women should do about exclusion from hazardous workplaces to protect any offspring they might conceive. See UAW v. Johnson Controls, Inc., 499 U.S. 187, 190 (1991). The two primary options presented to these women were to either a) treat women like men, in other words, let them work in the hazardous workplace; or b) treat women differently from men, in other words, forbid them from working in the hazardous workplace to accommodate women's difference. What should have been considered was the relationship of the hazardous workplace to men's fertility, as well. For a discussion of this case, see Reva Siegel, Reasoning from the Body: A Historical Perspective on Abortion Regulation and Questions of Equal Protection, 44 Stan. L. Rev. 261, 336-38 (1992) (addressing question of exclusion of fertile men as well as women). 
ing the same rights as man, or one takes an oppositional stance, constructing an alternative discourse. ${ }^{101}$

Binary constructions embody a logic that gives priority to the first term of the dyad, while subordinating the second. ${ }^{102}$ With binary structures, one term is given a positive value, which "constructs an 'other' of itself which signifies everything it does not accept. The second term is thus denied an existence of its own." 103 To remedy the limitations of binary discourse, a two-step strategy has been proposed. First, one renegotiates the valuation of the subordinate term. ${ }^{104}$ An example of this renegotiation would be the glorification of women's characteristics that differentiate them from men, for example, valuing traditionally unappreciated traits such as being caring and nurturing. ${ }^{105}$ Multiculturalist discourse attempts to do this by assigning greater value to the historically disparaged cultural identities of minority communities. ${ }^{106}$ But a second step is necessary to break the binary structure apart. This step is the process of displacement-the operation of locating the subordinate term in the heart of the dominant one. This makes the dependence of the subject on the "other" explicit. ${ }^{107} 1$ argue here that the feminist half of the feminism versus multiculturalism discourse is dependent on a particular "other" for its definition of self as relatively free from gender subordination. In constituting a specific feminist identity in opposition to multiculturalism, the suffering immigrant woman of color or Third World woman is constructed as the "other."

\section{How Culture Obscures}

Society's excessive focus on minority and Third World sex-subordinating cultural practices has four detrimental effects. First, it obscures the degree to which many "Third World women's problems" are rooted

101. For a discussion of sameness/difference debates in tbe context of both gender and race that suggests the need to dissolve the traditional dichotomy between sameness and difference, and to understand these arguments as about supposedly neutral standards that systematically disadvantage outsiders, see generally Joan C. Williams, Dissolving the Sameness/Difference Debate: A Post-Modern Path Beyond Essentialism in Feminist and Critical Race Theory, 1991 Duke L.J. 296, 299 (arguing for postmodern reformation of sameness and difference).

102. Lowe, supra note 59, at 24.

103. See Yegenoglu, supra note 88 , at 7 (describing work of Jacques Derrida in identifying "a binary structure that characterizes the discourse of metaphysics").

104. See id. at 7-9.

105. For a criticism of cultural feminism, see Margaret Jane Radin, Reply: Please Be Careful with Cultural Feminism, 45 Stan. L. Rev. 1567, 1568-69 (1993).

106. For a discussion of what can be the unfortunate result of attempts to revalue historically disparaged racial identities, see David L. Eng, Out Here and Over There: Queerness and Diaspora in Asian American Studies, 15 Social Text 31, 33-35 (1997) (documenting cultural nationalist project of Asian Americans in the 1970s and its use of sexism and homophobia in an attempt to reject mainstream imaging of Asian Americans as anomalous ethnic novelties).

107. See Yegenoglu, supra note 88 , at 8 . 
in forces beyond one's individual community, so that structural forces shaping cultural practices are hidden from view. Second, it directs attention away from issues affecting women that are separate from what are considered sexist cultural practices. Third, by positioning "other" women as perennial victims, it denies their potential to be understood as emancipatory subjects. And fourth, it diverts one's gaze from the sexism indigenous to United States culture and politics.

First, in concealing structural forces that shape cultural practices, what can be erased are forces that make culture. Specific cultural practices are connected to forces that deny women economic and political agency. These forces include global inequalities; new articulations of patriarchies in specific regions that are, for example, the result of emerging religious fundamentalisms; ${ }^{108}$ the legacies of colonialism and racism; ${ }^{109}$ and the flows of transnational capital.110 Our culture is not constructed within "hermetically sealed"11 boxes that travel with us from cradle to grave.

108. By fundamentalism, 1 mean modern political movements that use religion as a basis for their attempt to win or consolidate power and extend social control. See Clara Connolly \& Pragna Patel, Women Who Walk on Water: Working Across "Race" in Women Against Fundamentalism, in The Politics of Culture in the Shadow of Capital 375 (Lisa Lowe \& David Lloyd eds., 1998). As Connolly and Patel write, while fundamentalism appears in different and changing forms in religions throughout the world, at the heart of it all is the control of women's minds and bodies. All forms of fundamentalism support the patriarchal fanily as a central agent of control and see women as embodying the moral and traditional values of the family and the whole community. Id.

109. As an example of the role of colonialism, British colonial law destroyed communities that gave women more substantive rights than they were then given under colonial rule. In Kerala, in South India, British colonial law abolished the practice of matrilineality, eradicating women's ability to possess distinct rights to property as well as their control over households, by changing women's roles to be "mere conduits through whom descent and inheritance [could be] traced" and through establishing the oldest male members of households as the legitimate guardian of all other members. Kanakalatha Mukund, Women's Property Rights in South India: A Review, Economic and Political Weekly (May 29, 1999), availahle at http://www.epw.org.in/34-22/sa2.htm (last visited on Feb. 1, 2001) (on file with the Columbia Law Review); see also K. Saradamoni, Matriliny Transformed: Family, Law and ldeology in Twentieth Century Travancore 83 (1999) (describing impact of British in altering matrilineal practices so that husbands gained more rights over wives and property). Sudhir Chandra also documents the harmful role of colonial law in describing the case of a young woman named Rukhmabai who, married at eleven, and following another eleven years of unconsummated marriage and separate living, claimed she had been incapable of giving intelligent consent to the wedding and refused conjugal rights to the husband whom she had grown to strongly dislike. The British had imported into India the English legal practice of recognizing claims for the restitution of conjugal rights, and of enforcing this restitution by imprisonment which, thankfully, although Rukhmabai lost the case on appeal, she did not have to endure. Sudhir Chandra, Enslaved Daughters: Colonialism, Law and Women's Rights 1-5, 15-41, 161 (1998) (recounting story of "Rukhmabai and Her Case").

110. For an example of scholarship that links these factors to the existence of female genital surgeries, see Inderpal Grewal \& Caren Kaplan, Warrior Marks: Global Womanism's Neo-Colonial Discourse in a Multicultural Context, 39 Camera Ohscura 5, 7 (1996) [hereinafter, Grewal \& Kaplan, Warrior Marks].

111. Rosaldo, supra note 45 , at 44 . 
While culture is often represented as the product of timeless ritual insular to particular communities, such forces profoundly shape culture.

As an example, the historical practice of sati-immolation of a widow on her husband's funeral pyre-is consistently singled-out as an expression of Indian culture or Hindu religion, and is often described as caused by religious and wifely devotion. But sati was not constituted as a practice through "Indian culture" or "Hindu religion" alone. Feminist theorist Lata Mani has examined how the "tradition" of sati was constructed through the collaboration of British colonial officials and Hindu pundits who attempted to find a religious basis for the practice as the colonial government sought to determine the appropriate legislative response. ${ }^{112}$ Officials and missionaries constructed such a hasis by ignoring and marginalizing anything that did not accord with their presumptions. In individual descriptions of sati, even while European observers wrote of "wifely devotion" and a superstitious and barbarous religion, nothing in the widows' explanations pointed to a religious basis for sati. ${ }^{113}$ Instead, their explanations consisted of concerns for future subsistence and financial support, concerns that were explicitly material and social. ${ }^{114}$ However, with the involvement of the British colonial government, religion and culture were given the force of explanation, obscuring material reasons for the practice. Sati continues to be so understood, and in fact, is very often utilized in philosophical discourse to represent extreme cultural difference. ${ }^{115}$

As another example, amid the concern about gender apartheid under the Taliban, there has been little focus on the relationship between the intensification of religious fundamentalism and geopolitical economics. ${ }^{116}$ The United States gave aid to various mujahideen forces in

112. Mani, supra note 30 , at $192-93$.

113. Id. at 193.

114. 1d. at 167 .

115. See, e.g., Richard A. Posner, The Problematics of Moral and Legal Theory 10 (1999) (discussing pragmatic moral skepticism). Posner writes:

Had I been a British colonial official (but with my present values) in nineteenthcentury India, I would have outlawed suttee. This is an example of the rejection of vulgar relativism; the fact that suttee (the immolation-nominally, at least, voluntary-of the widow on her husband's bier) was an accepted practice of Hindu society did not make it morally binding on anyone outside that society. But I would have suppressed the practice because I found it disgusting, not because I found it immoral.

Id. at $10-11$.

116. See Feminist Majority Foundation Leaflet, Stop Gender Apartheid in Afghanistan (on file with the Columbia Law Review). While the leaflet does recognize some geopolitical relationships-mentioning that Pakistan "supports the Taliban with military aid and personnel, Saudi Arabia provides the Taliban with financial support," and that the petroleum industry may provide financial support for the regime-there is no explanation of the United States' role in training or funding the mujahideen who became the Taliban. Id. For a description of the United States' role, see William Blum, A Brief History of United States Intervention, 1945 to the Present, Z Magazine, at http://www.zmag.org/ zmag/articles/blum.htm (last visited Jan. 22, 2001) (on file with the Columbia Law Review); 
Afghanistan to fight the Soviets. From these mujahideen groups, the Taliban emerged. ${ }^{117}$ The United States aided General Zia of Pakistanwhose government adopted the notorious hudood ordinances that among other provisions criminalized extramarital sex, so that women who accuse men of rape or become pregnant risk punishment for adultery ${ }^{118}$-for the same reason. Feminists in the United States need to think critically about the relationship of this aid to states with policies inimical to women's concerns, instead of abstractly condemning lslam as the font of patriarchal oppression. ${ }^{119}$ At the same time, it is crucial for feminists to examine the importance of Christian fundamentalism within the United States and its effect on the lives of millions of women around the world through funding and development that structure reproductive practices and politics. ${ }^{120}$ Such an examination would lead to a more nuanced anal-

CIA-The World Factbook 2000-Afghanistan, <http://www.cia.gov/cia/publications/ factbook/geos/af.html> (last visited Jan. 28, 2001) (on file with the Columbia Law Review) (noting that the United States supplied and trained anticommunist mujahideen forces).

117. See Nancy Gallagher, The International Campaign Against Gender Apartheid in Afghanistan, 5 UCLA J. Int'l L. \& Foreign Aff. 367, 369-74 (Fall, 2000/Winter, 2001). Along these lines, many elements of other cultures that Americans criticize were facilitated by U.S. actions; for example, the history of political instability in Latin America has been shaped by U.S. involvement in supporting oligarchies that perpetuate radical inequalities of wealth. On U.S. involvement in sustaining oligarchies in Latin America, see Mark Gibney, United States' Responsibility for Gross Levels of Human Rights Violations in Guatemala from 1954 to 1996, 7 J. Transnat'l L. \& Pol'y 77, 82-87 (1997) (describing U.S. involvement in Guatemala).

118. Michael F. Polk, Women Persecuted Under 1slamic Law: The Zina Ordinance in Pakistan as a Basis for Asylum Claims in the United States, 12 Geo. Immigr. L.J. 379, 380 (1998). In 1979, under the martial law government of President Zia, five new laws, known as Hudood Ordinances, were adopted, that criminalize nonmarital rape, extramarital sex (including adultery and fornication), and various gambling, alcohol, and property offenses. The Hudood Ordinances were ostensibly adopted to bring the laws of Pakistan into "conformity with the injunctions of Islam." Asifa Quraishi, Her Honor: An lslamic Critique of the Rape Laws of Pakistan From a Woman-Sensitive Perspective, 18 Mich. J. Int'l L. 287, 288 (1997) (citations omitted). The most controversial of the ordinances has been the Zina Ordinance that created two new crimes: adultery and fornication (consensual intercourse outside a valid marriage by either previously married or unmarried persons). Id. at 288-89. Codifying adultery and fornication as crimes has led to the following situation: Women who seek redress for being raped, or are pregnant, have been subsequently convicted of adultery or fornication. Id. at 290-91.

119. For this point, see Inderpal Grewal \& Caren Kaplan, Introduction: Transnational Feminist Practices and Questions of Postmodernity, in Scattered Hegemonies: Postmodernity and Transnational Feminist Practices 1, 19-20 (1994) [hereinafter Grewal \& Kaplan, Transnational Feminist Practices]. For an example of feminist activism that suggests Islam is coequal with women's oppression, see E-mail forwarded from Lory D. Rosenberg to Leti Volpp et al. (Oct. 9, 2000) (requesting recipient to sign petition about the Taliban, and stating " $[\mathrm{e}]$ veryone has a right to a tolerable human existence, even if they are women in a Muslim country") (on file with the Columbia Law Review).

120. Grewal \& Kaplan, Transnational Feminist Practices, supra note 119, at 20. As 1 write this, President George W. Bush, as the first substantive action of his presidency, has issued an executive order barring United States aid for overseas programs that support abortion through surgery, counseling, or lobbying. Mike Allen, Bush Reverses Abortion 
ysis of differential birth rates in the global North and South than afforded by the often cited explanation that birth rates are the product of differing cultural valuations about the worth of male children. ${ }^{121}$

The second point is that the extreme focus on what is commonly conceptualized as cultural violence or subordination makes it difficult to see forces beyond culture. There are other important social, political, and economic issues affecting women's lives other than the cultural practices that garner so much attention. Only certain problems receive coverage or generate concern, namely those used to illustrate the alien and bizarre oppression of women of color; for example, sati, dowry death, veiling, female genital surgeries, female infanticide, marriage by capture, purdah, polygamy, footbinding, and arranged marriages. ${ }^{122}$ Other problemswhich raise questions of the role of dominant individuals, communities or states in shaping gendered subordination, such as ongoing relationships of economic inequity, development and community policies, exploitation by transnational corporations, or racism-are ignored.

As an illustration of this, Alice Walker and Pratibha Parmar made a film critical of female genital surgeries called "Warrior Marks," which has been the target of both intense praise and criticism. In the book they wrote to accompany the film, they recount an anecdote that describes a meeting between the filmmakers and a group of women who run a collective garden. ${ }^{123}$ Asked about their feelings about "female genital mutilation," the response of these women is to:

ask [] the "rich Americans" for a refrigerated truck they need badly to get their produce to outlying areas. The filmmakers,

Aid: U.S. Funds Are Denied to Groups That Promote Procedure Abroad, Wash. Post, Jan. 23,2001 , at Al.

121. Cf. Mary Ann Glendon \& Mary Haynes, Is Low Fertility Worth High Coercion? Providence J. (R.1.), Oct. 21, 1999, at B6. Glendon and Haynes criticize the assumption that voluntary family planning will work because women in the developing world want more children:

Among the semi-nomadic Pokot tribe in western Kenya, women with many children are honored after death with ritual burial, while the bodies of barren women are left out for the hyenas and vultures. In India, there have been reports of wives burned to death when they failed to produce sons. Id.

122. Martha Minow suggests that there is a fascination of:

the exotic and the erotic, associated with the sexual, the private, the home-and the female . . there does indeed seem to be something compelling, arresting, even captivating about stories of women murdered for male or family honor, or about the cutting of female genitals. Such stories simultaneously horrify and entice.

Minow, supra note 15 , at 128 . Importantly, she adds, these stories are both used to illuminate "otherness," but also seem to "echo something familiar . . . in the practices of the dominant Western nations." Id. Thus, the predominant role these stories play in the Western imagination reflects their importance in fixing the boundaries of us and the other.

123. Alice Walker \& Pratibha Parmar, Warrior Marks: Female Genital Mutilation and the Sexual Blinding of Women 253 (1993). 
who do not perceive themselves as "rich" by their own cultural standards, joke that they could probably only pay for one tire for such a truck. The request for a truck is not mentioned again. ${ }^{124}$

We could also think about this failure of vision through a parable told by the law professor Leslye Obiora, who wrote a story about mourners more concerned with the destruction of a beard by fire (which is meant to represent the clitoris, or the "blameless vulva") ${ }^{125}$ than with the death of the bearer of the beard (which is meant to represent a child who has died because of material deprivation). ${ }^{126}$ Obiora's parable was intended to demonstrate the tunnel vision of the feminists who insist on agitating against female circumcision without concern for the material well-being of those being circumcised-especially when many have made it clear that these are interrelated issues. ${ }^{127}$

124. Grewal \& Kaplan, Warrior Marks, supra note 110, at 21-22. Grewal and Kaplan write that:

"[t] he power to set an agenda, to arrive uninvited in a country for a brief period of time, to tell people how they ought to feel and think about their sexuality and their bodies, to assume the right to rescue other people's children, and to use this experience as a yardstick of one's own freedom," constitutes standard procedure in the cultural production of imperialism.

Id. at 22.

125. The "blameless vulva" is Alice Walker's term; she dedicates Possessing the Secret of Joy as follows: "This Book is Dedicated/With Tenderness and Respect/To the Blameless/ Vulva." Alice Walker, Possessing the Secret of Joy (1992). For a criticism of this as a preoccupation with women as "genital carriers," to the exclusion of the entire human being, see Micere Githae Mugo, Elitist Anti-Circumcision Discourse as Mutilating and AntiFeminist, 47 Case W. Res. L. Rev. 461, 468 (1997). She describes being invited to a panel to discuss Walker's book. The promoter called to ask for details. She writes: "I explained that 1 was an international scholar and Visiting Professor at Cornell University, a political activist, poet, and playwright. As if she had not heard me or thought what 1 had just said was of no relevance, she proceeded to ask me: 'Are you mutilated?'” $1 \mathrm{~d}$. at 469 .

126. Obiora, supra note 13 , at 77 .

127. Some might argue that female genital surgeries are not, in fact an appropriate site of feminist activity-for completely different reasons. Richard Shweder makes an argument about female genital surgeries that completely counters conventional feminist thinking on this subject, so much so that it is shocking. He points to the observations of an anthropologist from Sierra Leone, Fuambai Ahmadu, who chose to be circumcised at age twenty-two, and the research of medical anthropologist and epidemiologist Carla Obermeyer, who has reviewed the existing medical literature on female genital surgeries in Africa, to assert that assumptions about the health effects and effects on sexuality of "female genital mutilation" ("FGM") may not match reality. Ahmadu reported at the American Anthropological Association that the claims regarding the adverse effects on sexuality did not tally with her own experiences, and stated that she and other members of her community found the initiation ceremony empowering. Obermeyer's review indicated that most of the published literature either does not rely on data or relies on sensational testimonials, secondhand reports, or inadequate samples. Richard Shweder, What About "Female Genital Mutilation"? And Why Understanding Culture Matters in the First Place, Daedalus, Fall 2000, at 213. Judged against epidemiological research standards, Shweder suggests that the global discourse about the health and sexual consequences of the practice is not sufficiently supplied with credible evidence. Id. at 209. Shweder's article flies completely in the face of present assumptions about "FGM," suggesting that a considered response to the article may not be possible. 
The issues affecting immigrant or Third World women that receive the greatest attention are those that appear most easily identifiable as concerns to relatively privileged women in the West. These concerns include violations that threaten the freedom of movement, freedom of dress, freedom of bodily integrity, and freedom of control over one's sexuality, rather than violations of the right to shelter or basic sustenance. Thus, self-conception, in terms of what one fears for oneself, may play a role in generating concern about specific violations of women's rights.

The decision to focus on the issue of the cultural origins of violence against women rather than their material well-being also reflects a specific history. The focus on violence was a strategic one made by the "women's rights as human rights" movement. ${ }^{128}$ Male violence against women was believed to be the universal experience that could tie together women across the world, in the face of North-South divides that presented too much conflict among women regarding the issue of transnational economic equality. ${ }^{129}$ But the enormous success in creating a transnational "women's rights as human rights" movement that coalesced around the problem of the woman subject to male violence has served to shape what we envision as gender subordination. This strategy may contain limits as to what gains it can produce. ${ }^{130}$

128. See Keck \& Sikkink, supra note 68 , at 165-98. As they describe, at the International Women's Year Conference in Mexico City in 1975, the conference disintegrated into a heated debate among feminists from Western countries who stressed discrimination, and women from the developing world who stressed what they considered the more pressing issues of development and social justice that affected both men and women. Id. at 170 . The North-South tensions began to recede at the conference in Nairobi in 1985, the first one that made substantial recommendations on the issue of violence against women. The issue of women and development never spawned a major global network or campaign, with its "important but prosaic" demands: more credit opportunities for rural women, changes in laws about property rights and inheritance, more equitable sharing of work between men and women, training programs, improved access to water connections, roads, etc. Id. Global economic inequalities were so systemic that they defied individual or group efforts to effect change. Id. at 171 . In contrast, the issue of violence appeared to offer clearer avenues for activism. 1d. Keck and Sikkink describe how the category "violence against women" was constructed through this transnational activism, by unifying many practices that in the early 1970 s were not understood to be connected, such as "female genital mutilation" in Africa and domestic battery in the United States. Id. at 171-73.

Martha Fineman has made the suggestion that motherhood, or caring for dependents, would be a potential site of transnational feminist activity that would bring to the fore material conditions. Conversation with Martha Fineman, Professor of Law, Cornell University, at Cornell Law School (Nov. 29, 2000); see generally Martha Albertson Fineman, The Neutered Mother: The Sexual Family and Other Twentieth Century Tragedies 216 (1995) (arguing that dependency is an inevitable part of life and that society should financially support caregivers).

129. See Keck \& Sikkink, supra note 68 , at 171-72.

130. In pointing this out, I in no way intend to diminish the tremendous accomplishments of the "women's rights as human rights" movement. The hope is that transnational networks formed around the question of violence can be deployed to support activism around other concerns, and that these networks will not fragment around 
The insistent focus on immigrant and Third World women as victims also leads many to deny the existence of agency within patriarchy, ignoring that these women are capable of emancipatory change on their own behalf. ${ }^{131}$ The binary assumption that women in the West have choice, and that those in immigrant and Third World contexts have none, in part reflects the limits of our language in describing choice: Either one is an agent, or one is a victim. ${ }^{132}$ This binary also reflects historical representations of the West as the site of rugged individualism, and the East as the repository of passivity and culture. Furthermore, it reflects a legacy of feminist politics and theory that presents Third World women as bound by culture, as described above. This conceptualization has bled into discourses that can deny the subjectivity of immigrant and Third World women, ${ }^{133}$ both in terms of feminist empowerment ${ }^{134}$ and in terms of their

previous North-South divides. The notion that they will continue to be useful assumes that the figure of the woman, subject to violence, can easily transmutate into the woman, for example, subject to denial of basic subsistence. Lama Abu-Odeh's analysis of crimes of honor and crimes of passion, see Abu-Odeh, supra note 20, at 290-91, would lend skepticism to this notion, even considering different forms of violence. As she points out, despite the idea of international feminism that all violence against women across the world is the same, there remains a sharp difference between the Arab and American legal systems. In one the killing of daughters, sisters, and mothers for their sexual conduct is tolerated, while the killing of wives, ex-wives, girlfriends, and ex-girlfriends is tolerated in the other. Thus, the purported universality of the killing of "wives" is a cultural projection on other parts of the world. Id. at 290-91; see also Obiora, supra note 72, at 361 ("But what is this so-called 'global feminism?'").

131. The focus on women as victims also ignores that women can act as forces of conservatism. For a discussion on the relationship between women and right-wing movements, see Women and Right-Wing Movements: Indian Experiences 3-6 (Tanika Sarkar \& Urvashi Butalia eds., 1995) (focusing on activities of Hindu right in India).

132. As Lata Mani indicates, these poles preclude the possibility of a female subjectivity that is shifting, contradictory and inconsistent, and do not capture the dynamic and complex relation of women to social and familial expectations. Writing about the context of sati, she charges that the constrained notion of agency that underwrites women as always victims positions them as objects to be saved, never as subjects who act, even within incredibly restricted conditions. Mani, supra note 30, at 162. The "widows' valiant and persistent efforts at self-preservation and self-affirmation"-their narratives of terror, coercion, material distresses-have been occluded in constructing sati as a dutiful act of religious volition. Id. at 196. For a discussion of gender and agency and how both legal decisionmakers and feminist theorists have ascribed to women too little agency, see generally Kathryn Abrams, Sex Wars Redux: Agency and Coercion in Feminist Legal Theory, 95 Colum. L. Rev. 304, 304-07 (1995).

133. On recognizing subjectivity Maria Lugones writes:

Through traveling to other people's "worlds" we discover that there are "worlds" in which those who are the victims of arrogant perception are really subjects, lively beings, resistors, constructors of vision even though in the mainstream construction they are animated only by the arrogant perceiver and are pliable, foldable, file-awayable, classifiable.

Maria Lugones, Playfulness, "World"-Travelling, and Loving Perception, in Making Face, Making Soul: Haciendo Caras 390, 402 (Gloria Anzaldúa ed., 1990).

134. In the words of Sharon Hom, we must reimagine the "Others" of modernity as agents rather than victims, as "already possessing the power to transform their/our lives 
enjoyment of pleasure. ${ }^{135}$

A fourth effect of this intense focus on other women's sexist cultures is that it obscures violence at home, namely specific practices of violence against women within the United States, ${ }^{136}$ including those perpetrated by the state. The First World is seldom depicted as a violator in discussions of women's international human rights. For example, the obsessive focus on Muslim countries' "Islamic" reservations to the Convention on

and societies." Sharon K. Hom, Female Infanticide in China: The Human Rights Specter and Thoughts Towards (An) Other Vision, 23 Colum. Hum. Rts. L. Rev. 249, 310 (1992).

There is and has been tremendous feminist activity in the global South, belied by the often held assumption that feminism only exists in the United States and Europe. For a discussion of this activity, see generally Kumari Jayawardena, Feminism and Nationalism in the Third World 25-67, 73-253 (1986) (documenting late nineteenth and early twentieth century movements for women's participation in political struggles in Egypt, Iran, Turkey, India, Sri Lanka, China, Japan, Korea, the Philippines, Vietnam and Indonesia); Feminist Genealogies, Colonial Legacies, Democratic Futures, at xiii-xlii (M. Jacqui Alexander \& Chandra Talpade Mohanty eds., 1997) (collecting essays analyzing global feminist mobilization in the post-cold war era); Angela Y. Davis, Foreward to Global Critical Race Feminism: An International Reader xi, xii-xiii (Adrien Katherine Wing ed., 2000) (describing collection of essays on feminist activity worldwide); Hope Lewis, Between Irua and "Female Genital Mutilation": Feminist Human Rights Discourse and the Cultural Divide, 8 Harv. Hum. Rts. J. 1, 25-34 (1995) (describing efforts of African feminists to address female genital surgeries).

135. On pleasure, see Ratna Kapur, Postcolonial Erotic Disruptions: Legal Narratives of Culture, Sex, and Nation in India, 11 Colum. J. Gender \& L. (forthcoming 2001). Kapur seeks to displace the "body in flames with tbe dancing body in ecstasy," so as to disrupt the script that represents women in a "so-called developing context" as victims constantly in need of rescue to show they "are also interested in what lies behind Madhuri's blouse or under Chugtai's Lihaaf (The Quilt) or between the sheets in the Kama Sutra condom ads." Id.; see also Ratna Kapur, 'A Love Song to our Mongrel Selves': Hybridity, Sexuality and the Law, 8 Soc. \& Legal Stud. 353, 354 (1999) (examining importance of recuperating and theorizing desire and pleasure as a political project within postcolonial India); Gopinath, supra note 69, at 469 (examining relationship of queer South Asian diasporic subjectivity to national identity).

Whetber feminist tbeorizing in the realm of law understands women to experience sexual pleasure in general is another question. Katherine Franke suggests that feminist theorizing about law has largely neglected to discuss a positive theory of female sexuality. Sbe argues that this stems from legal feminism's focus on either maternalizing the female subject or conceptualizing sex as the inevitable site of danger for women. Katberine $M$. Franke, Theorizing Yes: An Essay on Feminism, Law, and Desire, 101 Colum. L. Rev. 181, 181 (2001). As Franke points out, other feminist disciplines do theorize pleasure and desire. ld. at 182 .

136. According to a 1998 survey, thirty-one percent of American women report being physically or sexually abused by a husband or boyfriend at some point in their lives. Thirty percent of Americans say they know a woman who has been physically abused by her husband or boyfriend in the past year. Nearly one-fifth of women reported experiencing a completed or attempted rape at some time in their lives. This violence occurs at similar rates across communities. Family Violence Prevention Fund, Domestic Violence is a Serious, Widespread Social Problem in America: The Facts, at http://www.fvpf.org/facts (last visited Feb. 6, 2001) (on file with the Columbia Law Review); see also Catharine A. MacKinnon, Comment: Disrupting Male Sovereignty: On United States v. Morrison, 114 Harv. L. Rev. 135, 141-45 (2000) (describing prevalence of violence against women in the United States). 
the Elimination of All Forms of Discrimination Against Women obscures the fact that the U.S. government has made reservations in the same manner. ${ }^{137}$ Both Muslim countries and the United States have entered sweeping reservations based on domestic law to the principle of equality-Muslim countries on the basis of Islamic law, and the United States on the basis of the U.S. Constitution. ${ }^{138}$ The United States has specifically interpreted broader treaty obligations that would require establishing the doctrine of comparable worth, introducing paid maternity leave, and promoting the full development of women and prohibiting discrimination, as enforceable only to the extent required by the U.S. Constitution. ${ }^{139}$ Although the specific reservations made are not identical to those made by Muslim countries, it has been argued that through these reservations, both countries refuse to recognize international obligations due to a domestic "sacred law."140 The "sacred law" of the United States is the U.S.

137. See Ann Elizabeth Mayer, Reflections on the Proposed United States Reservations to CEDAW: Should the Constitution Be an Obstacle to Human Rights? 23 Hastings Const. L.Q. 727, 739, 800-05 (1996) [hereinafter Mayer, Reflections]; see also Ann Elizabeth Mayer, Where Does the U.S. Stand on Women's Human Rights? Reflections in a Jaundiced Eye, Human Rights Postscript 18, 18 (on file with the Columbia Law Review) [hereinafter Mayer, Postscript] (discussing similarity between United States and Muslim countries' reservations to CEDAW); Catherine Powell, Introduction: Locating Culture, ldentity, and Human Rights, 30 Colum. Hum. Rts. L. Rev. 201, 205, 216-17 (1999) (asserting that failure of Western states to respect human rights because of constitutional, religious, or free market objections should be understood as based upon culture or relativism). Nations are not supposed to make reservations to a treaty they are ratifying based on a preference to uphold domestic law, especially not where the reservations run counter to the object and purpose of the treaty. Mayer, Postscript, supra, at 18. Mayer observes that although the United States is associated with the defense of human rights, it ironically "has shown extreme reluctance to integrate modern human rights within its domestic legal system, and has remained largely estranged from the modern system of international human rights law." Mayer, Reflections, supra, at 747. Catherine Powell points to the United States reservation to CEDAW with respect to the doctrine of comparable worth as reflecting concern about a perceived threat to market-based theories of supply and demand, which should be understood as reflecting a relativist, not a universalist perspective on human rights. Powell, supra, at 216-17.

138. Mayer observes that the United States is approaching the principle of equality for women in much the same way countries like Bangladesh, Egypt, and Libya have by entering reservations, understandings, and declarations to the equality norms of the Interuational Convenant on Civil and Political Rights and the Convention on the Elimination of All Forms of Discrimination Against Women. Mayer, Postscript, supra note 137 , at 18 .

139. See Convention on the Elimination of All Forms of Discrimination Against Women, 1249 U.N.T.S. 13 (1981). The United States has also invoked the Constitution in choosing not to follow a treaty obligation that would require assigning women to all military units in direct combat. Id.

140. Mayer, Reflections, supra note 137 , at 738 , 743. Joel Paul makes the point that this analogy is not truly appropriate, given that 1slamic law has a religious base, unlike the Constitution, which we acknowledge to be the product of a political process and subject to change. E-mail message from Joel R. Paul, Professor, University of California, Hastings, College of Law to Leti Volpp, Assistant Professor of Law, American University, Washington College of Law (Jan. 20, 2001, 17:48:06 CST) (on file with the Columbia Law Review). 
Constitution, which, by treating sex discrimination as less serious and harmful than racial discrimination, is used to deny the treaty obligations of international law. ${ }^{141}$

Thus, the excessive focus on the cultural devaluing of "other" women obviates the fact of sexism among majority communities or in Western states. ${ }^{142}$ The negative image of "other" women is used as a mirror of progress, so comparisons between women, as opposed to comparisons with men, become the relevant frame of reference for the discussion of human rights. ${ }^{143}$ By accepting the contention that their lives are superior to the lives of women from "other" cultures, the attention of many women is diverted from the fact that they continue to be subordinate to men within their own culture. ${ }^{144}$

\section{Conclusion}

1t may be easier to think of problems affecting minority and Third World women as solely the product of religious fundamentalism and barbaric culture, than to shift the focus of feminist practice in the manner 1 suggest above.

lt does not seem coincidental that the way some feminists have depicted gender oppression in immigrant and Third World communities reflects a failure to think about how women's concerns in those communities might implicate their own identities. There is a strong desire for innocence in many strands of feminist politics, ${ }^{145}$ supported by the defi-

Regardless, the reservations made by Muslim countries have overshadowed the failure by the United States to follow treaty obligations designed to improve the status of women.

141. Mayer, Reflections, supra note 137 , at $743,792$.

142. Uma Narayan writes that examples of Third World women's issues that successfully cross borders into Western national contexts are those that "seem 'Different,' 'Alien,' and 'Other," in comparison to "problems that seem 'similar' to those that affect mainstream Western women." Narayan, supra note 22, at 100 . As an example, she asserts that "clitoridectomy and infibulation have become virtually an 'icon' of 'African women's problems' in Western contexts, while a host of other 'more familiar' problems that different groups of African women face are held up at the border." Id.

143. Even when a problem is recognized to affect women in the First World as well as the Third, its framing may be very different. For example, Inderpal Grewal suggests that while "domestic violence is being acknowledged as a very large problem in the United States, it is framed as a 'health' concern rather than a human rights concern," so that strategies to combat violence are developing "through hospitals and health clinics, and not at the level of a human rights claim in the national or international legal system." Grewal, Women's Rights, supra note 19 , at 344 . This, she argues, suggests that "human rights for women can become meaningful only in relation to women in the Third World." Id.

144. For a similar expression of concern, see Laura Nader, Orientalism, Occidentalism and the Control of Women, 2 Cultural Dynamics 323, 323 (1989). As Nader writes, misleading cultural comparisons support contentions of positional superiority that divert attention from the processes that are controlling women in both Western and nonWestern states. 1d. at 323-24.

145. I mean here by innocence both the desire for the category "woman" to be pure and uncomplicated, unsullied by difference, as well as the desire not to be culpable for the disenfranchisement of others. Donna Haraway suggests, " $[w]$ hite women . . . discovered 
nition of the essential female identity of woman as victim of male violence. But an individual can be subordinated in one social relation and dominant in another. ${ }^{146}$ There is an ease with which one slips into a position of subordination, for example, as a woman subject to the discrimination of the glass ceiling, without seeing how this very subordinate location may simultaneously reflect privilege, for example, as one that relies on domestic labor and child care by immigrant women of color. ${ }^{147}$ The missionary impulse to save immigrant and Third World women from their subordination is rarely turned to uplift domestic workers from exploitative work situations. ${ }^{148}$ The repressive cultures of these women, on the other hand, are a subject of feminist concerns. Thus, women in the First World can feel as though they have autonomy and agency in contrast to women in the Third World, at the same time that they feel victimized by men in the First, but will not conceptualize themselves to be agents of subordinating practices. This absolution of responsibility rests on the assumption that relations between women are presumed to be non-oppressive, whereas the bonds of race are presumed to oppress wo-

(i.e., were forced kicking and screaming to notice) the noninnocence of the category 'woman.' That consciousness changes the configuration of all previous categories; it denatures them as heat denatures a fragile protein." Donna Haraway, A Manifesto for Cyborgs: Science, Technology, and Socialist Feminism in the 1980s, in Feminism/ Postmodernism 190, 199 (Linda J. Nicholson ed., 1990); see also Jane Flax, The End of Innocence, in Feminists Theorize the Political 445, 460 (Judith Butler \& Joan W. Scott eds., 1992) ("To take responsibility is to firmly situate ourselves within contingent and imperfect contexts, to acknowledge differential privileges of race, gender, geographic location, and sexual identities....").

146. Sherene H. Razack, Looking White People in the Eye: Gender, Race, and Culture in Courtrooms and Classrooms 13-14 (1998). Razack posits a theoretical framework that requires us to examine our own role in perpetuating oppression through investigating how systems of oppression interlock with each other, and provides the example of how domestic workers and professional women are produced so that neither exists without the other. 1d. at 13. As she and Mary Louise Fellowes point out, domestic workers have historically played a key role in the construction of middle class women, allowing the "lady" to distinguish herself as respectable by separating herself from contact with dirt. Mary Louise Fellowes \& Sherene Razack, The Race to Innocence: Confronting Hierarchical Relations among Women, 1 J. Gender, Race \& Just. 335, 347-48 (1998).

147. Martha Minow, Making All the Difference: Inclusion, Exclusion, and American Law 231 (1990). ("White women, for example, have often found a source of power in supervising women of color.").

148. For criticisms of this failure, see Taunya Lovell Banks, Toward a Global Critical Feminist Vision: Domestic Work and the Nanny Tax Debate, 3 J. Gender, Race \& Just. 1, 21-23 (1999) (criticizing feminist theory for failure to prioritize issues of paid household workers); Dorothy E. Roberts, Spiritual and Menial Housework, 9 Yale J.L. \& Feminism 51, 51 (1997) (same); Peggie R. Smith, Regulating Paid Household Work: Class, Gender, Race and Agendas of Reform, 48 Am. U. L. Rev. 851, 853 (1999) (same); see also Joan Williams, Unbending Gender: Why Family and Work Conflict and What to Do About 1t 162-63 (2000) (describing how white women have been able to use a privileged class and race position to alleviate gender disenfranchisement). Domestic service has always been a fraught site for feminism, since its existence bluntly raises power relationships between women, while at the same time, it is relied upon for the mobility of middle- and upper-class women. 
men of color. But this ignores the oppression of race and class among women. While to some extent this is understood in the context of the domestic politics of the United States, the innocence of the category "woman" seems to have been repackaged in the wrapping of the discourses of feminism versus multiculturalism and transnational women's rights.

A missionary feminist effort assuming West is Best incurs a defensive reaction from members of criticized communities, and thus plays into the hands of those who choose to defend sex subordinating behavior in the name of cultural nationalism. The cultural nationalist response to imperialist descriptions of other women functions as a problematic mirror image. Resistance becomes configured as the necessity of preserving culture, leading to the freezing of particular identifications of culture, ${ }^{149}$ which keeps women trapped within the binary logic. Blanket condemnation is less helpful in engendering dialogue than acknowledging that women in the West also have a problem with epidemic rates of male violence against women, sharing strategies that have been attempted to combat this violence, and asking how immigrant and Third World women are grappling with violence in their own communities. And beyond the mere equivalence of universal gender subordination, we also must understand and confront how gender subordination is related to other forces of subordination-including racism and transnational economic inequalities. This means paying attention to context, to the meaning of difference, and to global disparities of power.

We cannot simply accept the terms on which many have structured this debate. The assertion that women of color are to be saved from deviant cultures that pose a threat to "our" ideas, and the frequent response that this statement is Eurocentric or imperialist, are both equally impoverished. We need to progress from accusation and rejoinder and move beyond the dialectic that emerges from this binary. ${ }^{150}$

149. See Ahmed, supra note 62, at 167. As an example of this, Protestant missionaries led by the Church of Scotland Missionary Society began concerted efforts against female circumcision in Kenya in the 1920s. Missionary schools refused to admit circumcised girls, and church members could be suspended for requiring their girls to be circumcised. The missionaries argued that the operation was medically unnecessary and dangerous, and also that it was un-Christian because the associated rituals were pagan and overtly sexual. Keck \& Sikkink, supra note 68 , at 67-69. "The campaign took place in the context of increasing African opposition to British colonial practices, such as land alienation for European settlers, heavy hut and poll taxes, and an oppressive labor recruiting system." 1d. at 69. "The campaign against female circumcision became a symbol for colonial attempts to impose outside values and rules," and the nationalist elite began to defend the practice as "necessary to the preservation of traditional culture." Id. at 70. Female circumcision became associated with nationalism, independence, and anticolonial struggle. 1d. at $69-70$.

150. It is difficult to reach this question due to the energy that must be expended in clearing the brush of problematic representation. Because this representation is so ingrained in the literature, this Essay is devoted primarily to a critical, not constructive, project. My hope is that future dialogue can lead to constructive and creative interchange far beyond our present imaginings. Homa Hoodfar explains that one obstacle to this 
To be clear, the question of representation by feminists is far from the only problem plaguing women in immigrant or Third World communities. ${ }^{151} 1$ am not asking that we have no critical engagement with issues affecting communities in the Third World and communities of color. What 1 call for is not a refusal to criticize, but a more careful examination of the particularity of women's relationships to specific patriarchies, as well as to geopolitical and economic relationships. Attempts to make normative judgments and to change behavior must be premised on the understanding that cultures, including our own, are patriarchal-not more or less so, but differently patriarchal. We also need to understand cultures as characterized by resistance to patriarchy. When we consider the role of culture, we must not prioritize culture merely because we respect group rights, but should look to particular contexts in order to determine whether justifications of practices based on culture should be supported or not, depending on what subordination is forwarded or combated through such support. Such an analysis would simultaneously recognize the disenfranchisement due to racism and the legacies of colonialism, and recognize that this disenfranchisement has constructed the experiences of minority and Third World women in a way that is bound up with their experience of gender. We need to acknowledge both that culture shapes gender domination in any community, and that specific histories and present-day practices necessarily will mediate the understandings of what constitutes culture and how it shapes, hurts, or benefits our lives.

We must think creatively and in new ways. ${ }^{152}$ 1f, for example, we find that the transnational "women's rights as human rights" alliance con-

interchange is that when feminists deploy problematic representations of the women they seek to aid, they shut down discussion because one must first discuss the racism relied upon in critiquing the sexism. "[M] ust racism be used to fight sexism?" Hoodfar, supra note 41 , at 250 .

151. By asserting there are problems other than representation, I do not intend to indicate that representation and materiality are two separate constructs; I see them as imbricated in one another. For an interchange on the relationship between the discursive and material realms, see Martha C. Nussbaum, The Professor of Parody, The New Republic, Feb. 22, 1999, at 44-45 (reviewing Judith Butler's work and asserting that it focuses on the symbolic to the detriment of "women who are hungry, illiterate, violated, beaten."); Martha C. Nussbaum and Her Critics: An Exchange, The New Republic, Apr. 19,1999 , at 44 (questioning separation of materiality and symbolism as illustrated best in letters from Joan Scott and Drucilla Cornell).

152. I would also suggest that reform movements that are structured around the category "woman" and that pay no attention to other forces that may shape women's lives, can be not only unhelpful, but actually harmful. I am thinking here of reform efforts motivated to stop gendered violence in the lives of immigrant women that increase immigration controls, to the detriment of many, including these very women. For an example of how law designed to counteract the abuse of "mail order brides" has in fact had the opposite impact, see Nora V. Demleitner, In Good Times and In Bad: The Obligation to Protect "Mail-Order Brides," in Women and International Human Rights Law 613, 650-51 (Kelly D. Askin \& Dorean M. Koenig eds., 2000). To push reform efforts through legislative bodies frequently requires compromise, so that any measure that helps a 
structed to combat male violence against women cannot translate into global organizing against structural economic inequalities, what then? This would suggest that we think hard about new alliances or constructs that do not necessarily rely on the notion of the universal female subject. ${ }^{153}$

We will not reach new possibilities through a simplistic and binary freezing of difference and sameness, of women vis-a-vis men, and of "us" vis-a-vis minority and Third World communities. We need to learn to see and challenge the multiple, overlapping, and discrete oppressions that occur both within and across white/Western and Third World/nonwhite communities. Otherwise, we remain mired in the battle of feminism versus multiculturalism.

population also requires increasing control of that population in ways that can be problematic. Thus, in 1996, the Illegal Immigration Reform and Immigrant Responsibility Act not only mandated that international matchmaking organizations doing business in the United States disseminate information to immigrant spouses about their rights under current immigration laws, it also implemented measures designed to decrease marriage fraud. Illegal Immigration Reform and Immigrant Responsibility Act, $\$ 652,8$ U.S.C. $\$ 1375$ (Supp. 1997) (requiring every international matchmaking organization doing business in the United States to disseminate information regarding conditional permanent resident status and battered spouse waiver under such status, permanent resident status, and marriage fraud penalties, and requiring Attorney General to conduct study of mailorder marriages and report to Congress regarding, among other things, extent of marriage fraud in such marriages).

I53. An example of a new alliance might be the organizing of women under the rubric of "single women," a concept that provides linkages between women who are divorced, deserted, widowed, and never married, categories that include lesbians. This example makes apparent that the assumptions we may have about natural alliances, e.g., between lesbians and gay men, and assumptions we may have about alliances that would seem to have no salience, e.g., among single women of all sexual orientations, are dependent upon our Iocal context. See Written Out: How Sexuality Is Used to Attack Women's Organizing, at http://www.iglhrc.org/publications/books/WrittenOut/ index.html (last visited Feb. 27, 2001) (on file with the Columbia Law Review) (noting "political activism surrounding lesbian lives and identities" has taken place for many years within the context of organizing around issues of "single women" in India); Jelica Todosijevic, Serbia, in Unspoken Rules: Sexual Orientation and Women's Human Rights 17I, 172 (Rachel Rosenbloom ed., 1996) (describing discrimination against single women in Serbia and perception of lesbians as "single women").

Another example is the creation of My Sister's House, a new program for battered women and children, by Asian Resources, 1nc., in Sacramento, California. The organization works on economic development and job training, and decided to create a shelter after finding that a significant percentage of women who used the organization's services were experiencing domestic violence. Interview with Beckie Masaki, Director, Asian Women's Shelter, in San Francisco, Cal. (Jan. 21, 2001). What is interesting about this shelter is that it developed from a program concerned with economic security, not violence against women. It will be fascinating to see how this shapes the philosophy and work of My Sister's House. Because most battered women's shelters operate in a context of crisis services, follow-up services such as job skills and job training are typically underdeveloped. This new program starts from the vantage point of economics, not violence, and integrates anti-violence services into an overall set of services designed to respond to women's and children's economic needs. 
HeinOnline -- 101 Colum. L. Rev. [i] 2001 


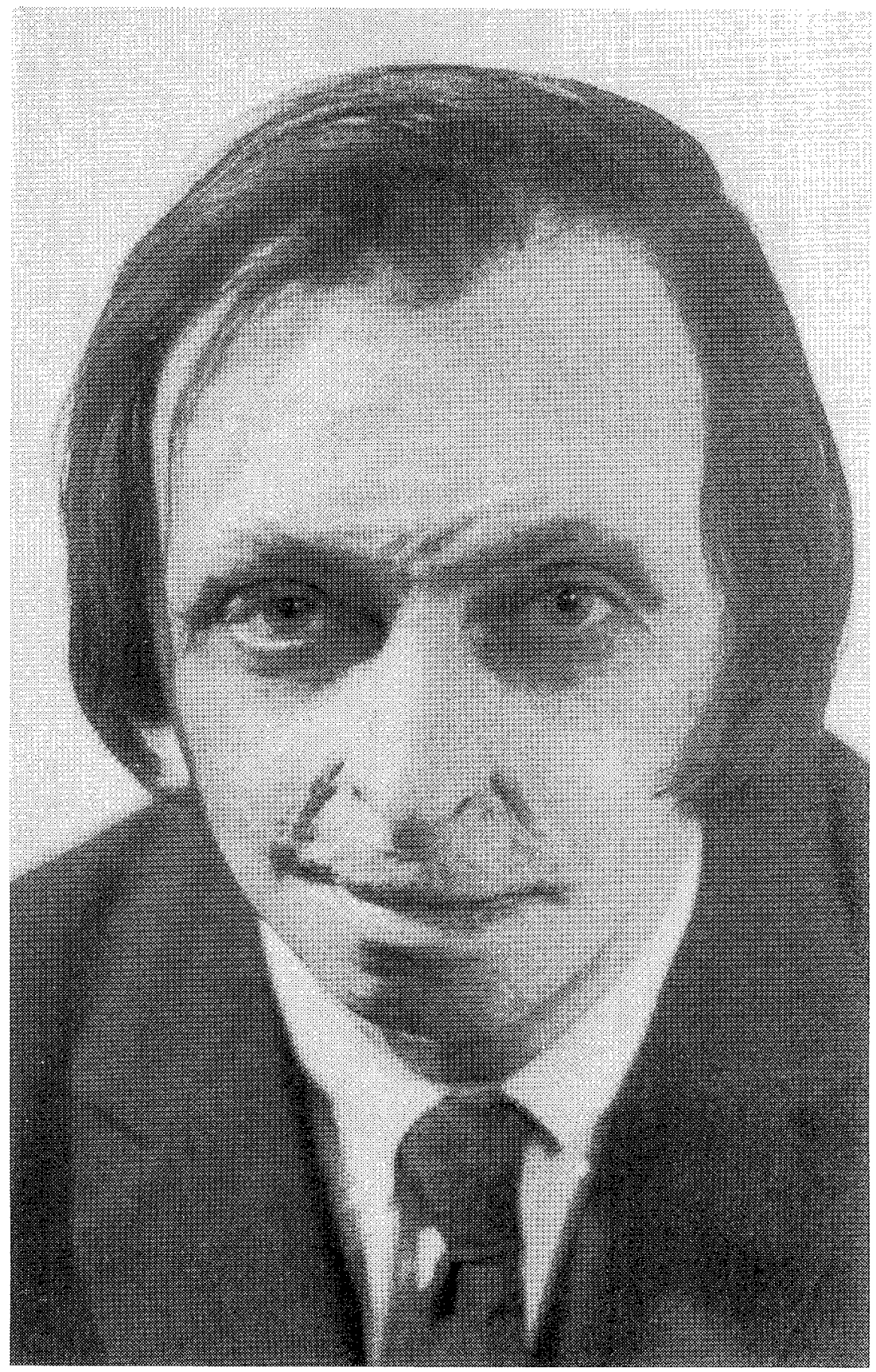

HAROLD L. KORN

HeinOnline -- 101 Colum. L. Rev. [ii] 2001 